Prepared in cooperation with the Hanalei Watershed Hui

\title{
Survey of Chemical Contaminants in the Hanalei River, Kaua'i, Hawai'i, 2001
}
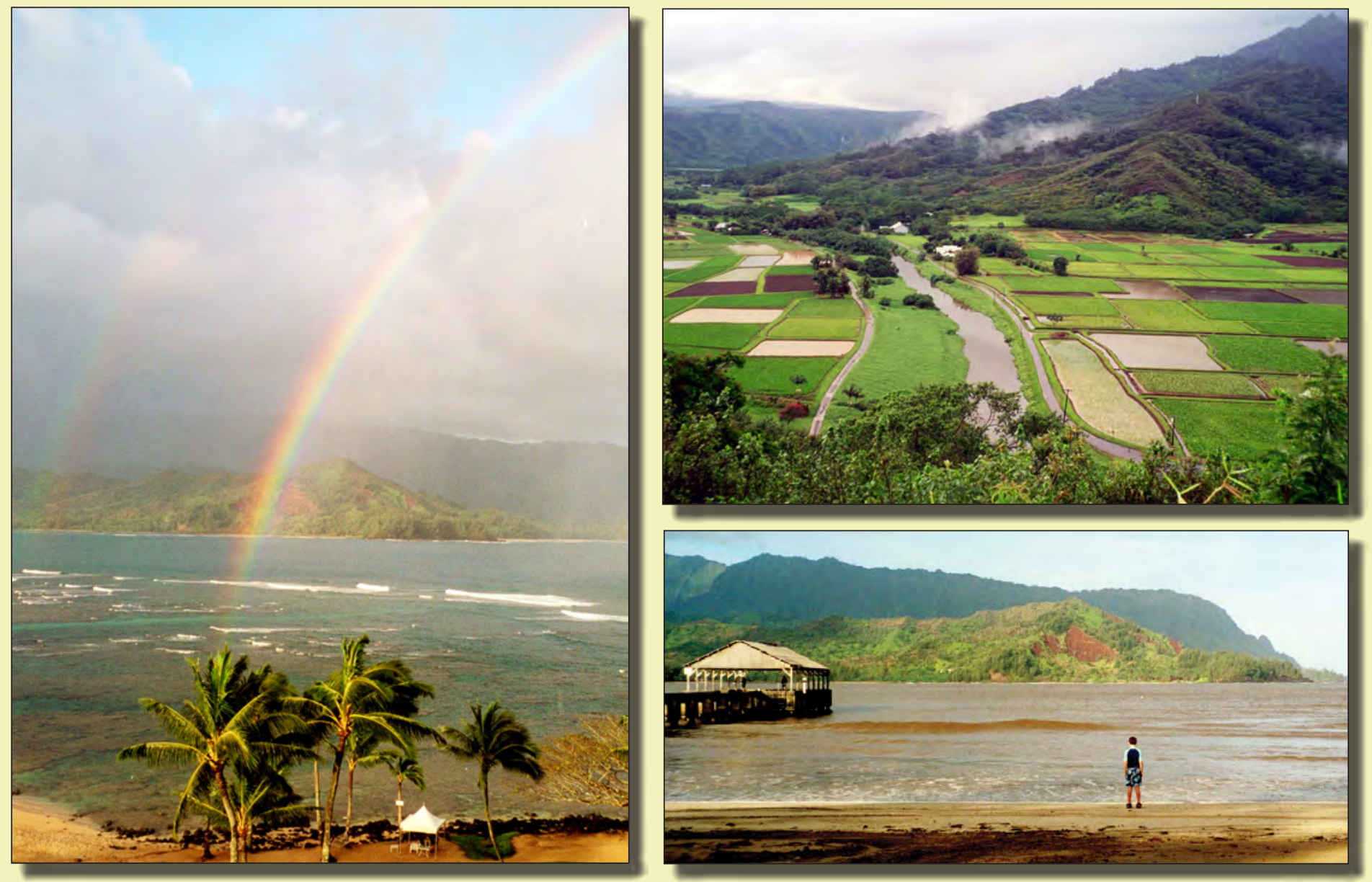

Scientific Investigations Report 2007-5096 
Cover. Rainbow over Hanalei Bay (left), Hanalei River flowing through the taro fields in the Hanalei National Wildlife Refuge (top right), and the sediment-laden bay near Hanalei Pier after a heavy rain event (bottom right). (Carl Orazio, U.S. Geological Survey, 2007) 


\section{Survey of Chemical Contaminants in the Hanalei River, Kaua'i, Hawai'i, 2001}

By Carl E. Orazio, Thomas W. May, Robert W. Gale, John C. Meadows, William G. Brumbaugh, Kathy R. Echols, William W.M. Steiner, and Carl J. Berg, Jr.

Prepared in cooperation with the Hanalei Watershed Hui

Scientific Investigations Report 2007-5096 


\section{U.S. Department of the Interior DIRK KEMPTHORNE, Secretary}

\section{U.S. Geological Survey \\ Mark D. Myers, Director}

\section{U.S. Geological Survey, Reston, Virginia: 2007}

For product and ordering information:

World Wide Web: http://www.usgs.gov/pubprod

Telephone: 1-888-ASK-USGS

For more information on the USGS--the Federal source for science about the Earth, its natural and living resources, natural hazards, and the environment:

World Wide Web: http://www.usgs.gov

Telephone: 1-888-ASK-USGS

Any use of trade, product, or firm names is for descriptive purposes only and does not imply endorsement by the U.S. Government.

Although this report is in the public domain, permission must be secured from the individual copyright owners to reproduce any copyrighted materials contained within this report.

Suggested citation:

Orazio, C.E., May, T.W., Gale, R.W., Meadows, J.C., Brumbaugh, W.G., Echols, K.E., Steiner, W.W.M., and Berg, Jr., C.J., 2007, Survey of chemical contaminants in the Hanalei River, Kaua'i, Hawai'i, 2001: U.S. Geological Survey

Scientific Investigations Report 2007-5096, 21 p. 


\section{Contents}

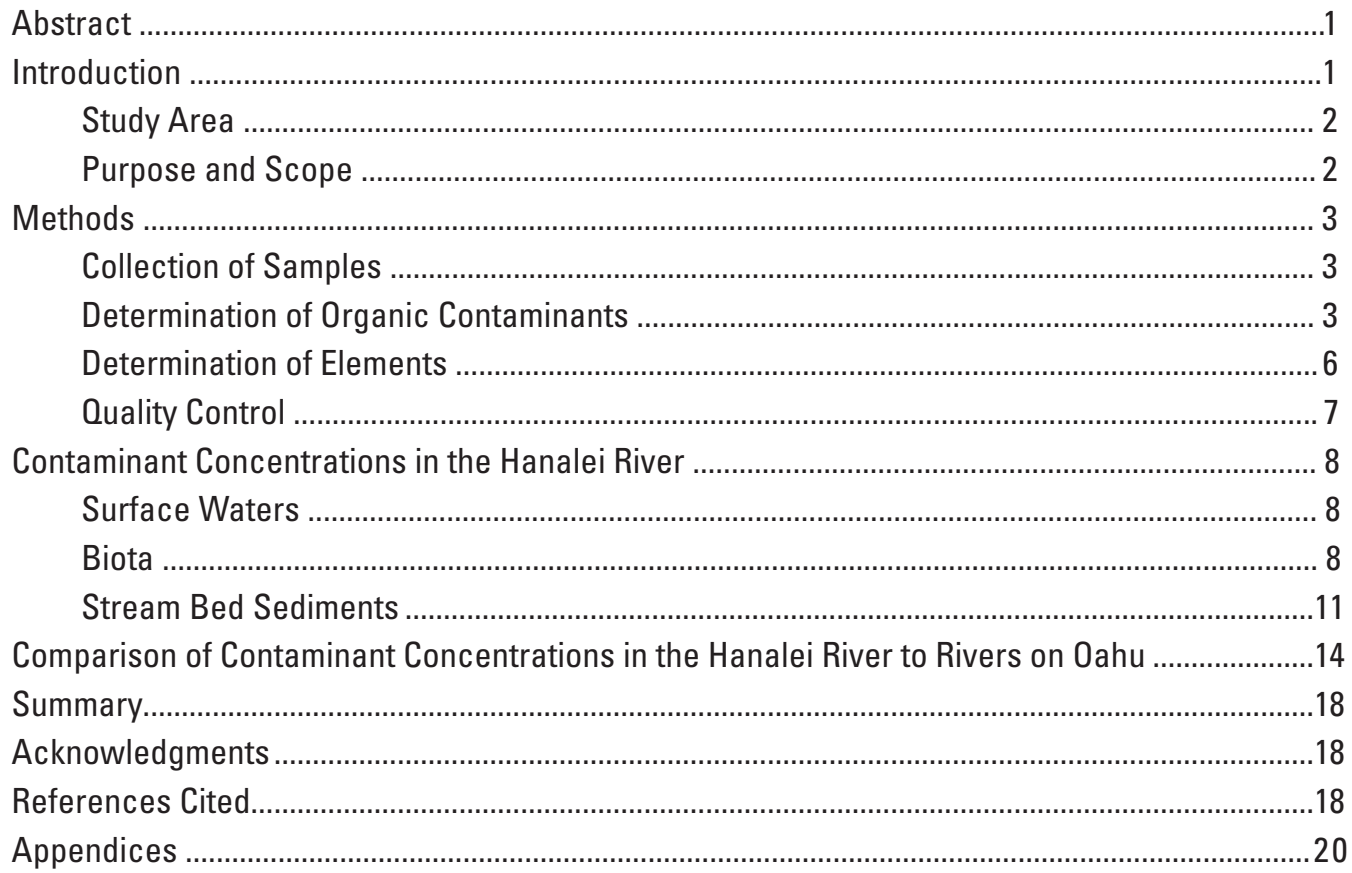

\section{Figures}

1-2. Maps showing-

1. Location of the study area on the Island of Kaua'i, Hawai'i ...............................................4

2. Location of upper and lower reach sampling sites on the Hanalei River, Kaua'i, Hawai'i, 2001

3. Comparison of gas chromatography/mass spectrometry analysis of Hanalei River surface water to that of a positive control sample containing polycyclic aromatic hydrocarbons

\section{Tables}

1. Hanalei River sampling sites and specimens collected December 4-11, 2001 ...............4

2. Concentrations of organochlorine pesticides and polychlorinated biphenyls in surface waters of the Hanalei River, December 2001

3. Concentrations of polycyclic aromatic hydrocarbons in surface waters of the Hanalei River, December 2001.

4. Concentrations of elements in surface waters of the Hanalei River, December 2001

5. Concentrations of organochlorine pesticides and polychlorinated biphenyls in Akupa sleeper fish (Eleotris sandwicensis), freshwater Asian clams (Corbicula fluminea), and giant mud crabs (Scylla serrata) of the Hanalei River, December 2001

6. Concentrations of elements in Akupa sleeper fish, freshwater Asian clams, and giant mud crabs of the Hanalei River, December 2001. 
7. Concentrations of organochlorine pesticides and polychlorinated biphenyls in stream bed sediment composites of the Hanalei River, December 2001.

8. Concentrations of polycyclic aromatic hydrocarbons in stream bed sediment composites of the Hanalei River, December 2001

9. Concentrations of elements in stream bed sediment composites of the Hanalei River, December 2001

\section{Conversion Factors, Datum and Acronyms}

SI to Inch/Pound

\begin{tabular}{|c|c|c|}
\hline Multiply & By & To obtain \\
\hline \multicolumn{3}{|c|}{ Length } \\
\hline micrometer $(\mu \mathrm{m})$ & 0.00003937 & inch (in.) \\
\hline millimeter $(\mathrm{mm})$ & 0.03937 & inch (in.) \\
\hline centimeter $(\mathrm{cm})$ & 0.3937 & inch (in.) \\
\hline meter $(\mathrm{m})$ & 3.281 & foot $(\mathrm{ft})$ \\
\hline kilometer $(\mathrm{km})$ & 0.6214 & mile (mi) \\
\hline \multicolumn{3}{|c|}{ Area } \\
\hline square meter $\left(\mathrm{m}^{2}\right)$ & 10.76 & square foot $\left(\mathrm{ft}^{2}\right)$ \\
\hline square kilometer $\left(\mathrm{km}^{2}\right)$ & 0.3861 & square mile $\left(\mathrm{mi}^{2}\right)$ \\
\hline \multicolumn{3}{|c|}{ Volume } \\
\hline microliter $(\mu \mathrm{L})$ & 0.00003381 & Fluid ounce (fl.oz) \\
\hline milliliter (mL) & 0.03381 & Fluid ounce (fl.oz) \\
\hline liter (L) & 0.2642 & gallon (gal) \\
\hline cubic centimeter $\left(\mathrm{cm}^{3}\right)$ & 0.06102 & cubic inch $\left(\mathrm{in}^{3}\right)$ \\
\hline cubic meter $\left(\mathrm{m}^{3}\right)$ & 35.31 & cubic foot $\left(\mathrm{ft}^{3}\right)$ \\
\hline cubic kilometer $\left(\mathrm{km}^{3}\right)$ & 0.2399 & cubic mile $\left(\mathrm{mi}^{3}\right)$ \\
\hline \multicolumn{3}{|c|}{ Flow rate } \\
\hline cubic meter per second $\left(\mathrm{m}^{3} / \mathrm{s}\right)$ & 35.31 & cubic foot per second $\left(\mathrm{ft}^{3} / \mathrm{s}\right)$ \\
\hline \multicolumn{3}{|c|}{ Mass } \\
\hline nanogram (ng) & $3.527 \times 10^{-11}$ & ounce, avoirdupois (oz) \\
\hline microgram $(\mu \mathrm{g})$ & $3.527 \times 10^{-8}$ & ounce, avoirdupois (oz) \\
\hline $\operatorname{gram}(\mathrm{g})$ & $3.527 \times 10^{-2}$ & ounce, avoirdupois (oz) \\
\hline \multicolumn{3}{|c|}{ Conversion } \\
\hline picogram/gram (pg/g) & $=$ & part per trillion (ppt; $10^{-12}$ ) \\
\hline nanogram/liter (ng/L) & $=$ & part per trillion (ppt; $10^{-12}$ ) \\
\hline nanogram/gram (ng/g) & $=$ & part per billion (ppb; $10^{-9}$ ) \\
\hline microgram/kilogram $(\mu \mathrm{g} / \mathrm{kg})$ & $=$ & part per billion (ppb; $\left.10^{-9}\right)$ \\
\hline microgram/liter $(\mu \mathrm{g} / \mathrm{L})$ & $=$ & part per billion (ppb; $10^{-9}$ ) \\
\hline microgram/gram $(\mu \mathrm{g} / \mathrm{g})$ & $=$ & part per million $\left(\mathrm{ppm} ; 10^{-6}\right)$ \\
\hline milligram/liter (mg/L) & $=$ & part per million $\left(\mathrm{ppm} ; 10^{-6}\right)$ \\
\hline
\end{tabular}

Temperature in degrees Celsius $\left({ }^{\circ} \mathrm{C}\right)$ may be converted to degrees Fahrenheit $\left({ }^{\circ} \mathrm{F}\right)$ as follows:

${ }^{\circ} \mathrm{F}=\left(1.8 \times{ }^{\circ} \mathrm{C}\right)+32$

Horizontal coordinate information is referenced to the North American Datum of 1983 (NAD 83) 
AA Atomic absorption

BEC Blank equivalent concentration

CCC Criterion continuous concentrations

CERC Columbia Environmental Research Center

CSeQC PEL Canadian Sediment Quality Guidelines-Probable Effect Level

DBC Dibutylchlorendate

DDD Dichlorodiphenyldichloroethane

DDE Dichlorodiphenyldichloroethylene

DDT Dichlorodiphenyltrichloroethane

ECD Electron capture detection

GC Gas chromatography

GC/ECD Gas chromatography with electron capture detector

GC/MS Gas chromatography/mass spectrometry

HNWR Hanalei National Wildlife Refuge

HCB Hexachlorobenzene

HCH Hexachlorocyclohexane

HCI Hydrochloric acid

$\mathrm{HNO}_{3}$ Nitric acid

HP-SEC High performance-size exclusion chromatography

ICP-MS Inductively-coupled plasma-mass spectrometry

LP-SEC Low pressure-size exclusion chromatography

MB Matrix blank

MDL Method detection limit

MOL Method quantitation limit

MS Mass spectrometry

MS Matrix spike

NAWQA National Water Quality Assessment Program

NIST National Institute of Standards and Technology

NYSDEC New York State Department of Environmental Conservation

OC Organochlorine (pesticides)

ODS Octadecylsilane

PAH Polycyclic aromatic hydrocarbon

PB Procedural blank

PCA Pentachloroanisole

PCB Polychlorinated biphenyls

PEL Probably effect level

POC Particulate organic carbon

PTFE Polytetrafluorethylene

QC Quality control

RSD Relative standard deviation

SD Standard deviation

TCMX Tetrachlorometaxylene

TOC Total organic carbon

USEPA U.S. Environmental Protection Agency

USFWS U.S. Fish and Wildlife Service

USGS U.S. Geological Survey 
This page intentionally blank. 


\title{
Survey of Chemical Contaminants in the Hanalei River, Kaua'i, Hawai'i, 2001
}

\author{
By Carl E. Orazio', Thomas W. May', Robert W. Gale', John C. Meadows', William G. Brumbaugh', \\ Kathy R. Echols ${ }^{1}$, William W.M. Steiner ${ }^{2}$, and Carl J. Berg, Jr. ${ }^{3}$
}

\section{Abstract}

The Hanalei River on the island of Kaua' $i$ in Hawai'i was designated an American Heritage River in 1998, providing special attention to natural resource protection, economic revitalization, and historic and cultural preservation. Agricultural, urban, and tourism-related activities are potential sources of contamination within the Hanalei River watershed. The objective of this study was to measure certain persistent organic chemicals and elements in the Hanalei River.

During a relatively low-flow period in December of 2001, samples of native Akupa sleeper fish (Eleotris sandwicensis), freshwater Asian clam (Corbicula fluminea), giant mud crab (Scylla serrata), surface water, and stream bed sediment were collected from a lower estuarine reach of the river near its mouth at Hanalei Bay and from an upper reach at the Hanalei National Wildlife Refuge. Samples were analyzed for residues of urban and agricultural chemicals including organochlorine pesticides, polychlorinated biphenyls, polycyclic aromatic hydrocarbons, and elements (including mercury, lead, cadmium, arsenic, and selenium). Organic contaminants were extracted from the samples with solvent, enriched, and then analyzed by gas chromatographic analysis with electron capture or mass spectrometric detection. Samples were aciddigested for semi-quantitative analysis for elements by inductively-coupled plasma-mass spectrometry and for quantitative analysis by atomic absorption spectrophotometry.

Concentrations of organochlorine pesticides, polycyclic aromatic hydrocarbons, and polychlorinated biphenyls in biota, surface water, and bed sediment sampled from the Hanalei River ranged from nondetectable to very low levels.

${ }^{1}$ U.S. Geological Survey, Columbia Environmental Research Center, 4200 New Haven Road, Columbia, Missouri 65201

${ }^{2}$ University of Hawai'i at Hilo, College of Agriculture, Forestry \& Natural Resource Management, 200 W. Kawili Street, Hilo, Hawai'i 96720

${ }^{3}$ Hanalei Watershed Hui, 5299C Kuhio Highway, P.O. Box 1285, Hanalei, Hawai'i 96714
Polychlorinated biphenyls were below detection in all samples. Dieldrin, the only compound detected in the water samples, was present at very low concentrations of 1-2 nanograms per liter. Akupa sleeper fish and giant mud crabs from the lower reach ranged from 1 to 5 nanograms per gram (wet weight) dieldrin and from less than 0.3 to 2.1 nanograms per gram total chlordane. Concentrations of individual polycyclic aromatic hydrocarbons in the lower reach bed sediments ranged from less than 1 to 190 nanograms per gram (dry weight). Relative concentrations (patterns) of the polycyclic aromatic hydrocarbons in one portion of a sediment sample indicated combustion sources. Concentrations of elements in the surface water, biota, and sediment samples were below toxicity thresholds of ecological concern. In summary, concentrations of the organic contaminants and elements targeted by this study of the Hanalei River in 2001 were below U.S. Environmental Protection Agency probable adverse effects levels for aquatic organisms.

\section{Introduction}

The Hanalei River on the island of Kaua'i in Hawai'i was designated as an American Heritage River in 1998, enabling the local community to receive Federal assistance for natural resource protection, economic revitalization, and historic and cultural preservation. Several endangered species of plants, fish, and wildlife inhabit the lush river valley. The river runs through the Hanalei National Wildlife Refuge (HNWR), a 3.7 square kilometer $\left(\mathrm{km}^{2}\right)$ refuge established in 1972. Much of the state's taro, a staple of the Hawaiian diet, is produced within the HNWR (U.S. Fish and Wildlife Service, 2006). The lower portion of the river forms the third largest state estuary and serves as a nursery and habitat for numerous fishes. Within the Hanalei River watershed are agricultural, urban, and tourism-related activities that are dependent upon the watershed's natural resources. 


\section{Study Area}

The Hanalei River is located on the north shore of the island of Kaua'i in Hawai'i (fig. 1). The 60- $\mathrm{km}^{2}$ Hanalei watershed begins at an elevation of 1,066 meters $(\mathrm{m})$ on the summit of Mount Waialeale, an area that annually receives 1,140 centimeters $(\mathrm{cm})$ of rain and is one of the wettest areas on Earth. Rainfall events can dramatically raise the river discharge in a matter of hours from a baseline of 2 cubic meters per second $\left(\mathrm{m}^{3} / \mathrm{s}\right)$ to over $100 \mathrm{~m}^{3} / \mathrm{s}$, rapidly flushing the river of recently deposited bed sediments (Calhoun and others, 2002). The river flows 26 kilometers ( $\mathrm{km})$ through wilderness, pastures, and cropland before emptying into Hanalei Bay. The mouth of the river is located between the town of Princeville and the town of Hanalei, near the Hanalei Pier. Two reaches of the river were selected for assessment of chemical contamination: a lower reach within $2 \mathrm{~km}$ of the mouth of the river and an upper reach within or just upstream of the HNWR (fig. 2).

\section{Purpose and Scope}

The purpose of this study was to measure certain persistent organic chemicals and elements in the Hanalei River in 2001. This study was a collaborative effort between the U.S. Geological Survey (USGS) Columbia Environmental Research Center (CERC), the Hanalei Watershed Hui, and the USGS Pacific Island Ecosystems Research Center. Monitoring of potential environmental stressors such as chemical pollution provides valuable information to managers of this river. Various samples were collected including unfiltered surface water, stream bed sediment, and aquatic biota. The aquatic biota sampled-the Akupa sleeper fish (Eleotris sandwicensis), freshwater Asian clam (Corbicula fluminea), and giant mud crab (Scylla serrata) - represent different ecosystem trophic levels that may bioaccumulate chemicals differently depending on the exposure pathway. Stream bed sediments were sampled because they act as a sink for certain chemical contaminants. The following chemicals commonly associated with urban and agricultural activities were assessed in this study (see Appendices for full description of the chemicals):

(1) Organochlorine $(O C)$ pesticides: aldrin, alpha-hexachlorocyclohexane $(\alpha-\mathrm{HCH})$, beta-HCH $(\beta-\mathrm{HCH})$, delta-HCH $(\delta-\mathrm{HCH})$, pentachloroanisole (PCA), heptachlor, heptachlor epoxide, cis-chlordane, oxychlordane, trans-chlordane, cisnonachlor, trans-nonachlor, $o, p^{\prime}$-dichlorodiphenyldichloroethane ( $o, p^{\prime}$-DDD), $p, p^{\prime}$-DDD, $o, p^{\prime}$-dichlorodiphenyldichloroethylene ( $o, p^{\prime}$-DDE), $p, p^{\prime}$-DDE, $o, p^{\prime}$-dichlorodiphenyltrichloroethane ( $p, p^{\prime}$-DDT), $p, p^{\prime}$-DDT, dimethyl tetrachloroterephthalate (DCPA), dieldrin, endosulfan I, endosulfan II, endosulfan sulfate, endrin, hexachlorobenzene (HCB), lindane, methoxychlor, mirex, and toxaphene. This list includes termiticides aldrin/dieldrin and chlordane, mosquito-control chemical
DDT, current-use pesticides such as lindane and hexachlorocyclohexanes, and pentachloroanisole, a degradant of the wood preservative pentachlorophenol.

(2) Polychlorinated biphenyls (PCBs): industrial chemicals used in many applications including electrical transformers, electrical ballasts, caulk, paint, and others.

(3) Polycyclic aromatic hydrocarbons (PAHs) and aliphatic hydrocarbons: The sixteen U.S. Environmental Protection Agency (USEPA) priority pollutant PAHs plus 1- and 2-methylnaphthalenes, dibenzothiophene, 2-methylphenanthrene, 4,5-methylene-phenanthrene, 1-methylphenanthrene, retene, 1-methylpyrene, benzo[b]naphtha[2,2-d]thiophene, benzo[e]pyrene, and perylene. Sources of PAHs include emissions of gasoline and diesel engines, combustion of coal/wood, creosote-treated wood, and runoff from fossil fuel-based materials, such as asphalt (Neff, 1979; Lebo and others, 1996; Petty and others, 2000). Aliphatic hydrocarbons also were analyzed in the water samples.

(4) Elements (approximately 60): The USEPA priority pollutant elements, including heavy metals mercury, cadmium, lead, and thallium, and the toxic elements arsenic and selenium.

Akupa sleeper fish, freshwater Asian clams, and giant mud crab tissues were analyzed for PCBs, OC pesticides, and elements. Stream bed sediments and surface waters were analyzed for PAHs, PCBs, OC pesticides, and elements, and screened for petroleum (aliphatic) hydrocarbons. Also, percent lipid of the biota, percent moisture of biota, concentration of particulate organic carbon (POC) in water and total organic carbon (TOC) of the sediments were measured. Hydrophobic organic contaminants tend to concentrate in lipid and sorb to POC and TOC (Lyman and others 1990).

Rivers in urban and agricultural areas may be impacted by other chemicals that were not targeted in this study. For example, the following chemical contaminants were not measured: volatile hydrocarbons; certain chemicals used to maintain lawns, golf courses, and roadside right-of-ways; chemicals associated with wastewater treatment effluents; and chemicals of emerging concern such as pharmaceuticals and personal care products. These other chemicals may include diazinon, trifluralin, pendamethalin, triazines, triazoles, carbamates, and organophosphates such as permethrin and chlorpyrifos, and selected degradation products (U.S. Fish and Wildlife Service, 2000; U.S. Geological Survey, 2006). Surfactants such as ethoxylated tallowamines (polyoxyethyleneamines) (U.S. Department of Agriculture, 1996; Wang and others, 2005) used in certain herbicide formulations were not measured in our study . 


\section{Methods}

\section{Collection of Samples}

Site selection and sampling supplies: Surface water, biota, and stream bed sediments were collected December 4-11, 2001 from a reach of the Hanalei River within two kilometers of its mouth (referred to as the lower reach) and from a reach within and just upstream of the HNWR (referred to as the upper reach) (fig. 2, table 1). Sampling equipment was certified as clean or was cleaned prior to use. Sample collection techniques followed guidelines of Schmitt and others (1981, 1990). Several samples were collected at each reach to provide sound statistical measure of contaminants at each reach.

Samples of surface water: Two unfiltered surface-water samples were collected from each reach for organic chemical analyses. At the time of sampling, the waters had little suspended river sediment and the water was quite clear. Unfiltered water samples were collected in 2.3 liter (L) amber bottles fitted with polytetrafluorethylene (PTFE)-lined caps. Water samples for elemental analyses were collected in 200 milliliter $(\mathrm{mL})$ polyethylene containers and preserved with $4 \mathrm{~mL}$ of 7 Molar ultrapure nitric acid $\left(\mathrm{HNO}_{3}\right)$. A bottle filled with deionized water to which acid was similarly added, served as a field blank for elemental analysis. All surface-water samples were placed on ice and shipped to the USGS-CERC for analyses. Water samples for organic chemical analysis were preserved with dichloromethane upon receipt by the USGS-CERC. Unfiltered waters were analyzed in all instances.

Samples of biota: Approximately 20 Akupa sleeper fish, the native Hawaiian O'opu akupa, were collected by hook and line or spear from each reach. The length of the fish ranged from 10 to $15 \mathrm{~cm}$; their composite weight was greater than 500 grams (g). They are highly predaceous on various invertebrates, such as snails and clams. These fish are relished by people as a food item. Twenty giant mud crabs were collected with nets at the lower reach only, as none were present in the upper reach. In Hawai'i, these giant mud crabs feed on an assortment of mollusks, crustaceans, and polychaetes, and are a sought-after food delicacy. More than 50 freshwater Asian clams with a composite weight greater than $500 \mathrm{~g}$ were collected from each reach. This small Asian clam feeds on plankton. In Hanalei, each group of samples was wrapped in clean, solvent-rinsed aluminum foil, placed inside polyethylene bags, frozen, and shipped to the USGS-CERC. Biota samples remained frozen at $-15^{\circ} \mathrm{C}$ prior to analysis.

Samples of stream bed sediment: The top 2-3 cm of stream bed sediment from five areas within each reach were collected with a polyvinyl chloride pipe sampler and then transferred into $0.5 \mathrm{~L}$ clean amber glass jars. Sediments were fine-grained particles less than $(<) 2$ millimeter $(\mathrm{mm})$ in diameter. Sediment samples were shipped cool on ice and remained refrigerated at 4 degrees Celsius $\left({ }^{\circ} \mathrm{C}\right)$ prior to analysis.

\section{Determination of Organic Contaminants}

Surface-water samples were prepared for gas chromatography/mass spectrometry (GC/MS) analysis of PAHs. The waters were extracted in separatory funnels with dichloromethane. Prior to extraction, 100 nanograms (ng) of each perdeuterated priority pollutant PAH surrogate was added. Quality control distilled water blanks and spiked distilled water samples were also analyzed. The dichloromethane extracts were filtered though anhydrous sodium sulfate, cleaned up by using high performance-size exclusion chromatography (HP-SEC), and reduced in volume by rotary evaporation and nitrogen blow-down to $0.25 \mathrm{~mL}$. The GC/MS analysis of the PAHs was performed with a Carlo-Erba GC8000 Top ${ }^{\mathrm{TM}}$ GC interfaced to a Finnigan Voyager ${ }^{\mathrm{TM}}$ quadrupole mass spectrometer (MS). A Carlo-Erba AS800 ${ }^{\mathrm{TM}}$ autosampler injected 2 microliters of the final extract from a 1-mL semi-conical amber vial onto a $2.5 \mathrm{~m}$ x 530 micrometer $(\mu \mathrm{m})$ deactivated fused silica retention gap via a cool on-column injection technique. A $50 \mathrm{~m}$ x $200 \mu \mathrm{m}$ GC column coated with 5 percent phenyl methylsilicone was used with an initial hold of 2.5 minutes (min) at $60{ }^{\circ} \mathrm{C}$, followed by a ramp to $300^{\circ} \mathrm{C}$ at $5{ }^{\circ} \mathrm{C} /$ $\mathrm{min}$, and held for $10 \mathrm{~min}$. Helium carrier gas was maintained at $1.00 \mathrm{~mL} / \mathrm{min}$ with an initial linear velocity of $\sim 35 \mathrm{~cm} / \mathrm{sec}$ ond (sec). The analytical column was directly connected to the MS through a transfer line maintained at $305^{\circ} \mathrm{C}$. The MS was tuned daily to unit mass resolution and calibrated using perfluorotributylamine. A single full-scan mass window of 50-450 mass to charge ratio, $0.75 \mathrm{sec}$ width, was used for the entire chromatographic run. Data acquisition began at $10 \mathrm{~min}$, prior to elution of naphthalene and was continued to elution of benzo $[g, h, i]$ perylene. Parent $(\mathrm{M}+)$ ions for each of the perdeuterated and native PAHs were monitored and used for quantitation. Spectra were verified by comparison to the standards and mass spectral library. The concentration of each PAH was inherently corrected for method recovery and other analytical variables by the isotope dilution method. Native PAH standards were matched to the response range of the samples. For positive identification and quantitation the following criteria were met: signal/noise limit greater than three $(\mathrm{S} / \mathrm{N}>3)$, and native PAH retention times were within 0.05 percent of the PAH surrogate. Those compounds without analytical standards, referred to as "tentatively identified compounds," were evaluated based on spectra and relative-retention times, and their concentrations were estimated using response factors of parent PAHs.

Samples of surface waters were prepared for GC with electron capture detection (ECD) analysis of OC pesticides and PCBs. Water samples were quantitatively extracted in separatory funnels three times with dichloromethane. The following internal recovery standards (40 ng each) were added prior to extraction: 2,4,5-trichlorobiphenyl (PCB 029), 2,2', 4,4',6,6'-hexachlorobiphenyl (PCB 155), 2,2',3,4,4',5,6,6' -octachlorobiphenyl (PCB 204), dibutyl- 


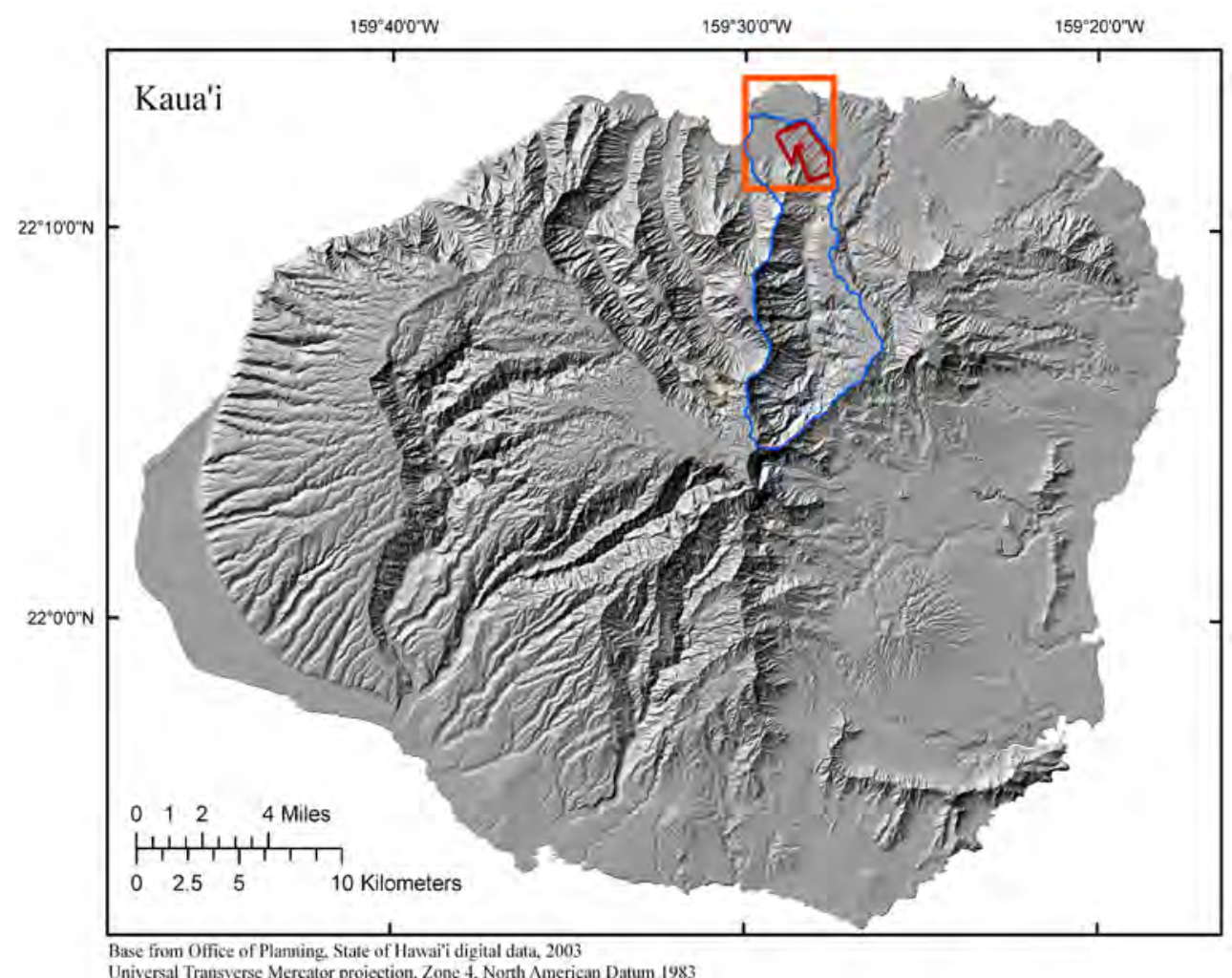

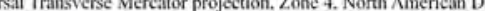
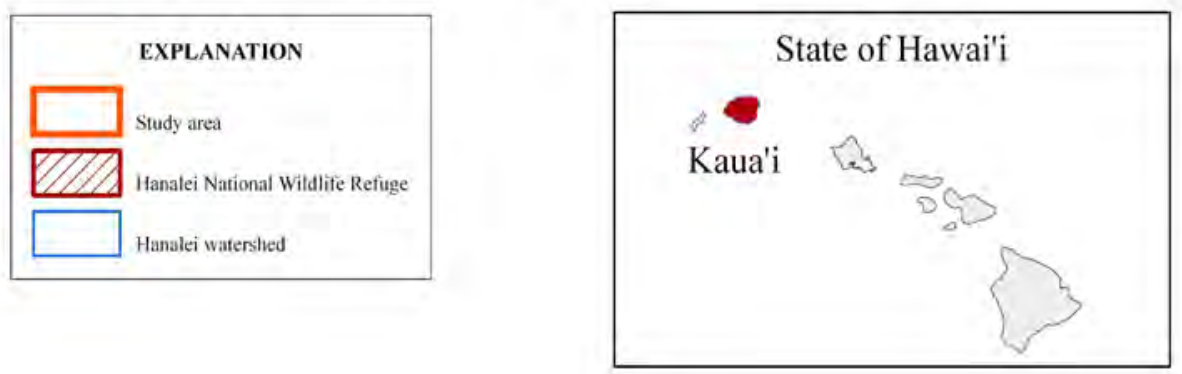

Figure 1. Location of the study area on the Island of Kaua'i, Hawai'i.

Table 1. Hanalei River sampling sites and specimens collected December 4-11, 2001. Samples included Akupa sleeper fish (Eleotris sandwicensis), freshwater Asian clam (Corbicula fluminea), giant mud crabs (Scylla serrata), surface water, and stream bed sediment.

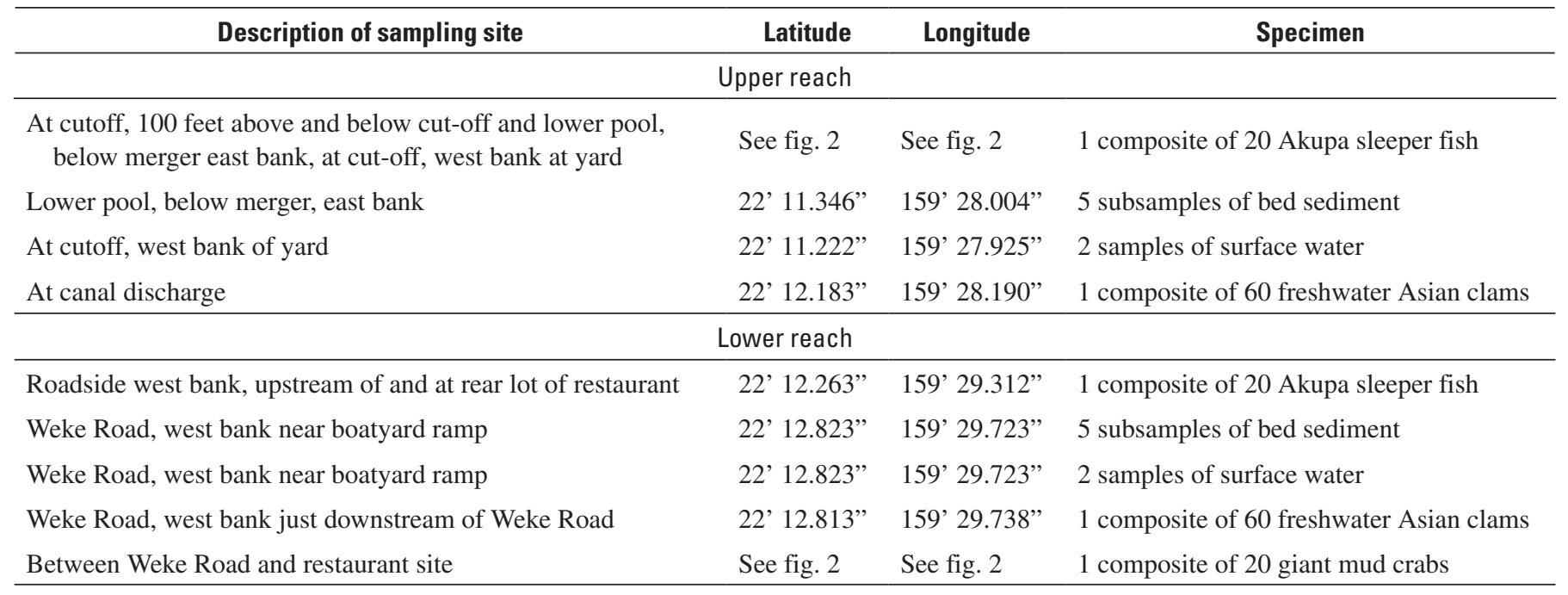




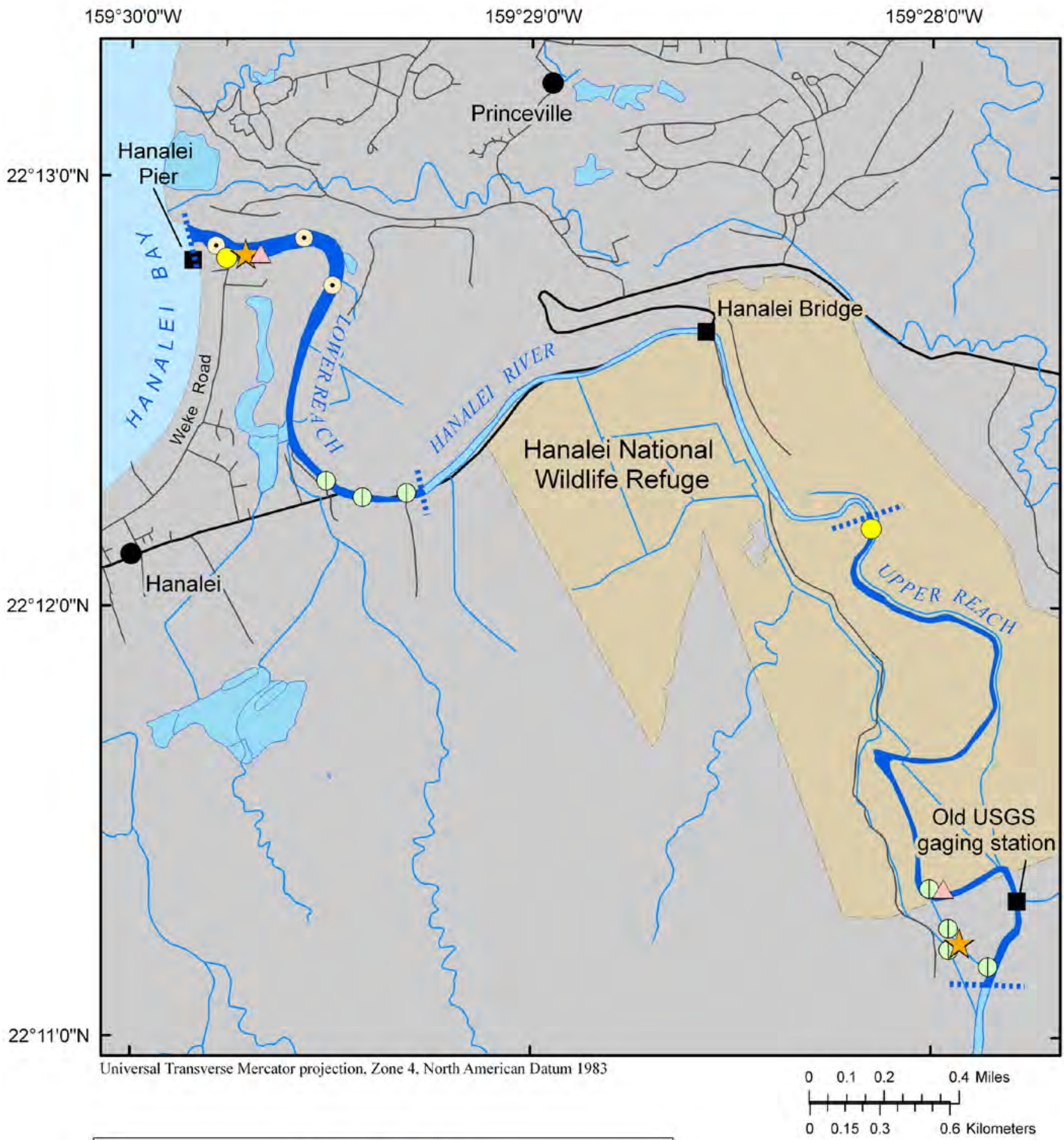

\section{EXPLANATION}

$\triangle$ Stream bed sediment $\bigcirc$ Freshwater Asian clam

¿ Surface water $\odot$ Giant mud crab

...... Sampling reach extent (1) Akupa sleeper fish

Figure 2. Location of upper and lower reach sampling sites on the Hanalei River, Kaua'i, Hawai'i, 2001. 
chlorendate (DBC), and tetrachlorometaxylene (TCMX). The dichloromethane extracts were filtered though anhydrous sodium sulfate. Pesticides and PCBs were fractionated by silica gel-octadecylsilane (ODS) chromatography and rotary evaporated to $1 \mathrm{~mL}$. Eighty nanograms of each instrumental internal standard, PCB congeners 2,4,6-trichlorobiphenyl (PCB 030), and 2,2',3,3',4,4',5,6,6'-nonachlorobiphenyl (PCB 207), were added. Analyses were performed using HP 5890 Series $^{\mathrm{TM}}$ II GC systems with cool on-column capillary injection systems and HP model $7673^{\mathrm{TM}}$ autosamplers. A 3-m section of 0.53-mm inner diameter uncoated and deactivated capillary retention gap was connected with a Press-Tight ${ }^{\mathrm{TM}}$ union. The dual analytical columns were a $60 \mathrm{~m} \times 0.25 \mathrm{~mm}$ $0.25 \mu \mathrm{m} 5$ percent phenyl with 95 percent methylsilicone, and a $60 \mathrm{~m} \times 0.25 \mathrm{~mm} 0.25 \mu \mathrm{m} 50$ percent phenyl with 50 percent methylsilicone. The hydrogen-carrier gas was pressure-regulated at 170 kilopascals (KPa), equivalent to $25 \mathrm{psi}$. The GC temperature program was $60^{\circ} \mathrm{C}$ initially, ramped to $150{ }^{\circ} \mathrm{C}$ at $15{ }^{\circ} \mathrm{C} / \mathrm{min}$, then to $250{ }^{\circ} \mathrm{C}$ at $1{ }^{\circ} \mathrm{C} / \mathrm{min}$, and finally to 320 ${ }^{\circ} \mathrm{C}$ at $10^{\circ} \mathrm{C} / \mathrm{min}$, with $1 \mathrm{~min}$ final hold. The ECD temperature was $330^{\circ} \mathrm{C}$. Data were processed with Perkin Elmer Turbochrom $^{\mathrm{TM}}$ software. Six levels of PCB calibration standards (200 to $8,000 \mathrm{ng} / \mathrm{mL}$ total-PCBs) were used to quantitate approximately 130 individual congeners. The method detection limit (MDL) or method quantitation limit (MQL) was calculated as follows using mean and standard deviation (SD) of several method blanks (Keith, 1991):

$\mathrm{MDL}=$ Mean (blank) $+3 \mathrm{SD}$, which represents the 95 percent confidence interval.

$\mathrm{MQL}=$ Mean (blank) + 10 SD which corresponds to the 99 percent confidence interval.

Samples of biota were prepared for GC/ECD analysis of OC pesticides and PCBs. Carapace and claw soft tissues from four of the larger of the giant mud crabs having carapace widths of 13.5, 12.0, 10.0, and $6.5 \mathrm{~cm}$ were mixed together and homogenized. Whole-body Akupa sleeper fish samples were ground to a coarse consistency and a composite of each reach was created. Recovery standards of PCB 029, PCB 055, PCB 204, DBC, and TCMX, were added to the 10-g portions of each type of biota sample. Procedural blanks (PB), bluegill-matrix blanks (MB), and bluegill-matrix spikes (MS) were analyzed with the samples. The MS received $400 \mathrm{ng}$ of each of the 24 pesticides and 1,000 ng of PCBs. The samples were dried by mixing with anhydrous sodium sulfate and then extracted in glass columns with dichloromethane. A portion of the extract was used for percent lipid determination. Extracts were enriched with low pressure-size exclusion chromatography (LP-SEC) and HP-SEC. Then extracts were fractionated into PCB and pesticide fractions with silica gel-ODS chromatography. Extracts were reduced in volume to $2 \mathrm{~mL}$ and analyzed by GC/ECD using the method described above.
Samples of stream bed sediment were prepared for GC/ECD analysis of OC pesticides and PCBs, in addition to GC/MS analysis of PAHs. Overlying water was decanted from the jar and the stream bed-sediment samples were homogenized. Composites were created using equal portions from five jars of sediment taken from sampling sites at each reach. Remaining portions of sediment were returned to storage at $-15{ }^{\circ} \mathrm{C}$. (Note: Inorganic analyses were performed on individual jars of sediment.) Percent moisture and total organic carbon were determined. Sediment aliquots $(15 \mathrm{~g})$ were spiked with perdeuterated PAHs (surrogates), pesticide and PCB recovery compounds, and then mixed with anhydrous sodium sulfate to form a dry free-flowing sample. The sediments were extracted with dichloromethane in a Soxhlet apparatus for 8 hours and then split for PAH and pesticide/PCB cleanup procedures. Elemental sulfur was removed from the sediment extracts with both activated copper and HP-SEC procedures. The pesticides and PCB fractions were purified and analyzed using GC/ECD as described above for the biological tissue samples. The PAH extract was purified and fractionated with potassium silicate and silica gel (both nondestructive) to produce aliphatic and aromatic fractions. Extracts were reduced in volume to 0.25 $\mathrm{mL}$ and analyzed using GC/MS as described above for the water samples.

\section{Determination of Elements}

Surface water samples were prepared for semi-quantitative scan analysis of elements using inductively-coupled plasma-mass spectrometry (ICP-MS). Atomic absorption spectrophotometry (AA) was used for analysis of arsenic, selenium, and mercury. Duplicate water samples were collected and analyzed. A surface-water sample of $5 \mathrm{~mL}$ was placed into a $50 \mathrm{~mL}$ quartz reaction vessel, and $1 \mathrm{~mL} \mathrm{HNO}_{3}$ was added and heated to $180^{\circ} \mathrm{C}$ in a Perkin-Elmer Multiwave ${ }^{\mathrm{TM}} 3000$ Digestion System. After cooling, digestates were transferred to a storage container and diluted to a final volume of $50 \mathrm{~mL}$ of high purity water. Quality control included digestion blanks and blank spikes, reference solutions and materials, sample replicates, sample spikes, repeated runs of a reference solution, and internal standards.

Biota samples were prepared for ICP-MS scan and AA analyses of arsenic, selenium, and mercury. Ground homogenates of the Akupa sleeper fish samples and of the five giant mud crab samples were created. Soft body tissues of freshwater Asian clams, claw and carapace tissues of giant mud crabs, and whole-body Akupa sleeper fish samples were ground separately to a coarse consistency and dried by lyophilization. The percent moisture was determined. Dried samples were ground to a coarse powder and stored in glass jars in a desiccator prior to analysis. A homogenized portion of each biota sample $(0.25 \mathrm{~g})$ was heated with $5 \mathrm{~mL} \mathrm{HNO}_{3}$ in a sealed 
100-mL microwave PTFE vessel to $180{ }^{\circ} \mathrm{C}$. The digested sample was transferred into a $125 \mathrm{~mL}$ polyethylene bottle with ultrapure water and brought to a final weight of $101.5 \mathrm{~g} \mathrm{(100}$ $\mathrm{mL}$ ) using 5 percent $\mathrm{HNO}_{3}$. For subsequent mercury determination, $30 \mathrm{~mL}$ of this solution was transferred to a glass tube containing $0.3 \mathrm{~mL}$ of hydrochloric acid $(\mathrm{HCl})$.

Samples of stream bed sediment were prepared for ICPMS scan and AA analyses. Samples were lyophilized and then digested with $5.5 \mathrm{~mL} \mathrm{HNO}_{3}+0.5 \mathrm{~mL} \mathrm{HCl}$ to determine total recoverable metals (refractory mineral phases in sediment are not measured by this procedure). The digested sample and solids were transferred and diluted as described above for biota. A portion of the digested sample $(30 \mathrm{~mL})$ was sealed in a glass tube containing $0.15 \mathrm{~mL} \mathrm{HCl}$ for subsequent mercury determination.

All samples were analyzed for total recoverable metals by ICP-MS using a semiquantitative scan mode (TotalQuant ${ }^{\mathrm{TM}}$ ). This method typically measures the elements with an accuracy of 30-50 percent error. Sample digestates were prediluted 10 fold by a CETAC ASD-500 ${ }^{\mathrm{TM}}$ autodiluter as part of the analytical sequence. Internal standards included scandium, rhodium, and thorium each at 10 parts per billion (ppb). The external standard was a National Institute of Standards and Testing (NIST) traceable reference solution to which five elements (praseodymium, terbium, thulium, tantalum, and gold) were added for improved calibration in the rare-earth region of the mass-spectral range.

All samples were analyzed for arsenic and selenium by hydride generation AA spectrophotometry. A 20-mL or $\sim 0.25$-g portion of each sample was dry-ashed with $\mathrm{HNO}_{3}$ and magnesium nitrate. The procedure consisted of three steps: (1) boiling with $\mathrm{HNO}_{3}$ for solubilization and partial oxidation, (2) ashing at $500{ }^{\circ} \mathrm{C}$ with magnesium nitrate for completion of oxidation and decomposition of remaining organic matter, and (3) heating with $\mathrm{HCl}$ to dissolve the ash and reduce selenium to the $\mathrm{Se}^{+4}$ oxidation state required for hydride generation. The reduction procedure does not affect arsenic, which was therefore determined as $\mathrm{As}^{+5}$. Digestates were diluted to $\sim 100 \mathrm{~mL}$ with deionized water, yielding a final acid matrix of 10 percent $\mathrm{HCl}$. Digestates were mixed with an $\mathrm{HCl}$ carrier solution and then reduced by sodium tetrahydridoborate stabilized with sodium hydroxide. The resulting volatile hydrogen selenide or arsenide was carried into a heated AA quartz cell with argon gas.

Mercury concentrations in biota and stream bed sediment were determined by flow injection cold vapor AA spectrophotometry, whereby mercury vapor produced by reaction with stannous chloride was swept into a $100{ }^{\circ} \mathrm{C}$ quartz cell. Mercury was not measured in the water because it is normally present at extremely low concentrations that require special collection and analysis protocols that were not part of this study.

\section{Quality Control}

The quality control (QC) results for the organic contaminant analyses were within acceptable limits based on established specifications for each respective method. Method detection limits for all the targeted compounds were similar to CERC historical values; the matrix and procedural blanks analyzed with all the sample types had normal concentrations of background contaminants. The extraction efficiencies and methodological accuracy were monitored by periodic analysis of positive control samples including in-house reference materials. Samples with low recoveries were reanalyzed. All field duplicates of the water samples and all analytical duplicates and triplicates of the stream bed sediments and biota were in agreement with each other, except for the PAH results in one of five portions in the sediment from the lower reach, as described in the Results section.

The trace-element analyses QC results indicate the data are of high quality and within acceptable limits based on broadly established specifications for each respective method. In summary, reference material data were in agreement with target values. (The QC data is not shown in tables; it is available upon request.) Recovery rates for reference water samples ranged 81-119 percent, with the exception of 156 percent for aluminum and 168 percent for barium. Recoveries for analysis of the three tissue-reference materials ranged 77-124 percent with the exception of 185 percent for aluminum and 158 percent lead in one sample and 160 percent tin in another. These higher recovery rates, both in reference solutions and tissues, may be caused by interferences inherent in the matrix of the materials and thus not directly relevant to Hanalei samples. Total recoverable elements compared well with total metals NIST values of the reference materials: 62-107 percent was observed for lithium, magnesium, chromium, manganese, iron, cobalt, nickel, copper, zinc, arsenic, cadmium, barium, thallium, and lead; expected differences were due to differences in the methodological intentions. The recoveries were in agreement with historical values measured by CERC. Recoveries of mercury, selenium, and arsenic were within the recommended limits except for two cases of mercury in tissues that slightly exceeded upper limits.

Analytical precision for the semi-quantitative scans were $<18$ percent relative standard deviation (RSD). Instrumental precision for arsenic, selenium, and mercury was $<6$ RSD. In the ICP-MS semi-quantitative scans, internal standards responses were stable, varying $<8$ percent during the analysis. Method precision for surface water, biota, and stream sediments as determined by triplicate digestion and analysis yielded percent RSDs $<45$ percent. Percent RSDs for arsenic, selenium, and mercury were $<26$ percent. Recoveries were determined for elements spiked into samples. Ranges for recoveries of surface water samples were 64-146 percent and averaged 102 percent. Recoveries for biota samples were 
105-137 percent and averaged 115 percent, excluding a high cadmium recovery in one spike ( 242 percent). The range of recoveries for stream bed sediment samples was 61-127 percent and averaged 94 percent, excluding poor recoveries for chromium (51 percent) and molybdenum (1 percent and 4 percent). Ranges for arsenic, selenium, and mercury recoveries were 84-112 percent and averaged 100 percent. Ranges of recoveries for postdigestion spikes of arsenic, selenium, and mercury were 92-109 percent and averaged 102 percent. Elemental background interference or "blank equivalent concentrations" (BEC) were below USGS reporting limits for the semi-quantitative scan. The BECs for arsenic, selenium, and mercury were less than the method detection limits, except for one mercury BEC. None of the data was corrected for BEC.

\section{Contaminant Concentrations in the Hanalei River}

\section{Surface Waters}

It is worth noting that the flow rate (discharge) of the Hanalei River varies dramatically throughout the year. The sampling period for this study, December 4-11, 2001, was preceded by several months of moderate flows that ranged from about 2.5 to $5.7 \mathrm{~m}^{3} / \mathrm{s}$ [90-200 ft $3 / \mathrm{s}$ (cubic feet per second)], punctuated by a two-day increased discharge that ranged from 32 to $43.3 \mathrm{~m}^{3} / \mathrm{s}\left(1,120\right.$ to $\left.1,530 \mathrm{ft}^{3} / \mathrm{s}\right)$ on November $26-27$, 2001 (U.S. Geological Survey, 2007). Following this pulse, discharge returned to a range of 3.9 to $9.3 \mathrm{~m}^{3} / \mathrm{s}$ (136 to 330 $\mathrm{ft}^{3} / \mathrm{s}$ ). The surface water samples for the 2001 study were clear and contained few visible suspended sediments.

Under low flow conditions, the water is relatively clear; however, during heavy rainfall events and higher discharge, mobilized sediment and soil turn the river and bay a rustybrown color. (Note the color of the Hanalei Bay water in the cover photo taken near the Hanalei Pier on the morning after a mean daily discharge of $65 \mathrm{~m}^{3} / \mathrm{s}\left(2,300 \mathrm{ft}^{3} / \mathrm{s}\right)$ (U.S. Geological Survey, 2007).

Dieldrin, the only organic compound detected, was found at extremely low levels $(1-2 \mathrm{ng} / \mathrm{L})$ in water samples collected from both the upper and lower reaches (tables 2,3). The concentration of dieldrin was well below the USEPA Freshwater Criterion Continuous Concentration (CCC) of $56 \mathrm{ng} / \mathrm{L}$ for filtered water (U.S. Environmental Protection Agency, 1999). These waters were screened by semi-quantitative GC/MS method for aliphatic hydrocarbons (indicative of petroleum oils) and for neutral compounds typical of urban effluents, such as caffeine and nonylphenol ethoxylates; however, none of these compounds were found.
As noted above, PAHs were not detected in the Hanalei River surface waters. As a QC measure and to illustrate PAH contamination of water, we used a positive control water sample from Jackson Lake, Wyoming contaminated by exhaust from a 4-cycle boat motor. The GC/MS chromatogram for the positive control lake water sample shows PAHs and alkylated PAHs detected (fig. 3, table 3).

Concentrations of elements in Hanalei River surfacewater samples were generally very low (table 4 ). A few elements, including aluminum, manganese, iron, and rubidium were above reporting limits. As expected, there were marked differences between the upper reach freshwater samples and lower reach estuarine water samples for the major elements sodium, magnesium, potassium, calcium, and iron, and for the minor elements lithium, aluminum, manganese, zinc, and strontium. Waters from the lower reach contained sodium, magnesium and strontium at concentrations of 860,000, 105,000 , and 750 micrograms per liter $(\mu \mathrm{g} / \mathrm{L})$ respectively, all of which are approximately 10 percent their concentration in seawater. Elemental water concentrations were less than the USEPA CCC for chromium, iron, nickel, copper, zinc, arsenic, and selenium (1999). The aluminum CCC of $87 \mu \mathrm{g} / \mathrm{L}$ was exceeded in water samples at all reaches; however, all Hanalei water samples were unfiltered, so the resulting aluminum concentrations may have been due to particulates in the water. Concentrations of copper and molybdenum were higher in one blank than in water samples from upper and lower reaches. Duplicate samples produced similar results with one exception of lead in the upper reach duplicates, which measured $1 \mu \mathrm{g} / \mathrm{L}$ versus $17 \mu \mathrm{g} / \mathrm{L}$. Because these samples were true field duplicates, the $17 \mu \mathrm{g} / \mathrm{L}$ concentration in one of the duplicate pairs was likely a result of random contamination that occurred during collection and/or processing for analysis.

\section{Biota}

Concentrations of OC pesticides and PCBs in the biological tissue samples were extremely low and in most cases below detection (table 5). Heptachlor epoxide, oxychlordane, cis/trans-nonachlors, $p, p^{\prime}$-DDE, $p, p^{\prime}$-DDD, and dieldrin were detected in the giant mud crabs at the lower reach. Akupa sleeper fish had traces of cis/trans-nonachlors and dieldrin. No pesticides were detected in tissue samples from the upper reach, a finding that correlated with the results of the sediment and water analyses, with very low to nondetectable concentrations found. Residues of the $\mathrm{OC}$ pesticide toxaphene were also analyzed but were not detected in the biota. The biota samples were not analyzed for PAHs because fish tend to metabolize PAHs and clams are not particularly good accumulators of PAHs, primarily because of their low percentage of lipid content ( 0.6 percent in this study).

Concentrations of dieldrin and chlordane in the Akupa sleeper fish of the Hanalei River were below the Canadian 
Table 2. Concentrations of organochlorine pesticides and polychlorinated biphenyls in surface waters of the Hanalei River, December 2001.

[ng/L, nanogram per liter; <, less than; DDE, dichlorodiphenyldichloroethylene; DDD, dichlorodiphenyldichloroethane; DDT, dichlorodiphenyltrichloroethane; endrin had low recovery and is not reported]

\begin{tabular}{|c|c|c|c|c|c|c|c|}
\hline \multirow{2}{*}{$\begin{array}{l}\text { Organochlorine pesticide or } \\
\text { polychlorinated biphenyl }\end{array}$} & \multicolumn{2}{|c|}{ Upper reach ${ }^{1}$} & \multicolumn{2}{|c|}{ Lower reach ${ }^{2}$} & \multirow{2}{*}{$\begin{array}{c}\text { Quality control } \\
\begin{array}{c}\text { Trip blank } \\
\text { (ng/L) }\end{array}\end{array}$} & \multirow{2}{*}{$\begin{array}{c}\text { Method } \\
\text { detection limit } \\
\text { (ng/L) }\end{array}$} & \multirow{2}{*}{$\begin{array}{l}\text { Recovery } \\
\text { (percent) }\end{array}$} \\
\hline & $\begin{array}{c}\text { Sample } 1 \\
\text { (ng/L) }\end{array}$ & $\begin{array}{c}\text { Sample } 2 \\
\text { (ng/L) }\end{array}$ & $\begin{array}{c}\text { Sample } 1 \\
\text { (ng/L) }\end{array}$ & $\begin{array}{c}\text { Sample } 2 \\
\text { (ng/L) }\end{array}$ & & & \\
\hline Hexachlorobenzene (HCB) & $<1$ & $<1$ & $<1$ & $<1$ & 0.24 & 1 & 78 \\
\hline Pentachloroanisole (PCA) & $<2$ & $<2$ & $<2$ & $<2$ & 0.34 & 2 & 88 \\
\hline $\begin{array}{l}\text { alpha-hexachlorocyclohexane } \\
\qquad(\mathrm{HCH})\end{array}$ & $<0.1$ & $<0.1$ & $<0.1$ & $<0.1$ & 0.01 & 0.1 & 90 \\
\hline beta-HCH & $<1$ & $<1$ & $<1$ & $<1$ & 0.17 & 1 & 91 \\
\hline Lindane & $<0.5$ & $<0.5$ & $<0.5$ & $<0.5$ & $<0.01$ & 0.5 & 92 \\
\hline delta-HCH & $<0.5$ & $<0.5$ & $<0.5$ & $<0.5$ & 0.03 & 0.5 & 93 \\
\hline Heptachlor & $<0.1$ & $<0.1$ & $<0.1$ & $<0.1$ & 0.02 & 0.1 & 81 \\
\hline Heptachlor epoxide & $<1$ & $<1$ & $<1$ & $<1$ & 0.15 & 1 & 100 \\
\hline $\begin{array}{l}\text { Dimethyl tetrachloroter- } \\
\text { ephthalate (DCPA) }\end{array}$ & $<1$ & $<1$ & $<1$ & $<1$ & 0.10 & 1 & 91 \\
\hline Dieldrin & 1.0 & 1.4 & 2.0 & 1.5 & 0.22 & 1 & 97 \\
\hline Oxychlordane & $<1$ & $<1$ & $<1$ & $<1$ & 0.28 & 1 & 99 \\
\hline cis-Chlordane & $<0.5$ & $<0.5$ & $<0.5$ & $<0.5$ & 0.01 & 0.5 & 101 \\
\hline trans-Chlordane & $<0.5$ & $<0.5$ & $<0.5$ & $<0.5$ & 0.04 & 0.5 & 98 \\
\hline cis-Nonachlor & $<0.5$ & $<0.5$ & $<0.5$ & $<0.5$ & 0.01 & 0.5 & 93 \\
\hline trans-Nonachlor & $<0.1$ & $<0.1$ & $<0.1$ & $<0.1$ & 0.01 & 0.1 & 99 \\
\hline$o, p^{\prime}-\mathrm{DDE}$ & $<0.5$ & $<0.5$ & $<0.5$ & $<0.5$ & 0.01 & 0.5 & 87 \\
\hline$o, p^{\prime}-\mathrm{DDD}$ & $<2$ & $<2$ & $<2$ & $<2$ & 0.52 & 2 & 89 \\
\hline$o, p^{\prime}-\mathrm{DDT}$ & $<0.1$ & $<0.1$ & $<0.1$ & $<0.1$ & 0.01 & 0.1 & 97 \\
\hline$p, p^{\prime}-\mathrm{DDE}$ & $<1$ & $<1$ & $<1$ & $<1$ & 0.11 & 1 & 93 \\
\hline$p, p^{\prime}-\mathrm{DDD}$ & $<0.2$ & $<0.2$ & $<0.2$ & $<0.2$ & 0.03 & 0.2 & 90 \\
\hline$p, p^{\prime}$-DDT & $<0.5$ & $<0.5$ & $<0.5$ & $<0.5$ & 0.04 & 0.5 & 96 \\
\hline Endosulfan I & $<1$ & $<1$ & $<1$ & $<1$ & 0.10 & 1 & 102 \\
\hline Endosulfan II & $<0.5$ & $<0.5$ & $<0.5$ & $<0.5$ & 0.00 & 0.5 & 90 \\
\hline Endosulfan sulfate & $<1$ & $<1$ & $<1$ & $<1$ & 0.28 & 1 & 98 \\
\hline Methoxychlor & $<3$ & $<3$ & $<3$ & $<3$ & 1.0 & 3 & 109 \\
\hline Mirex & $<0.1$ & $<0.1$ & $<0.1$ & $<0.1$ & 0.00 & 0.1 & 94 \\
\hline $\begin{array}{l}\text { Total polychlorinated } \\
\text { biphenyls (PCBs) }\end{array}$ & $<50$ & $<50$ & $<50$ & $<50$ & 30 & 50 & 100 \\
\hline
\end{tabular}

${ }^{1}$ Particulate organic carbon was 330 micrograms per liter in the upper reach.

${ }^{2}$ Particulate organic carbon was 480 micrograms per liter in the lower reach. 


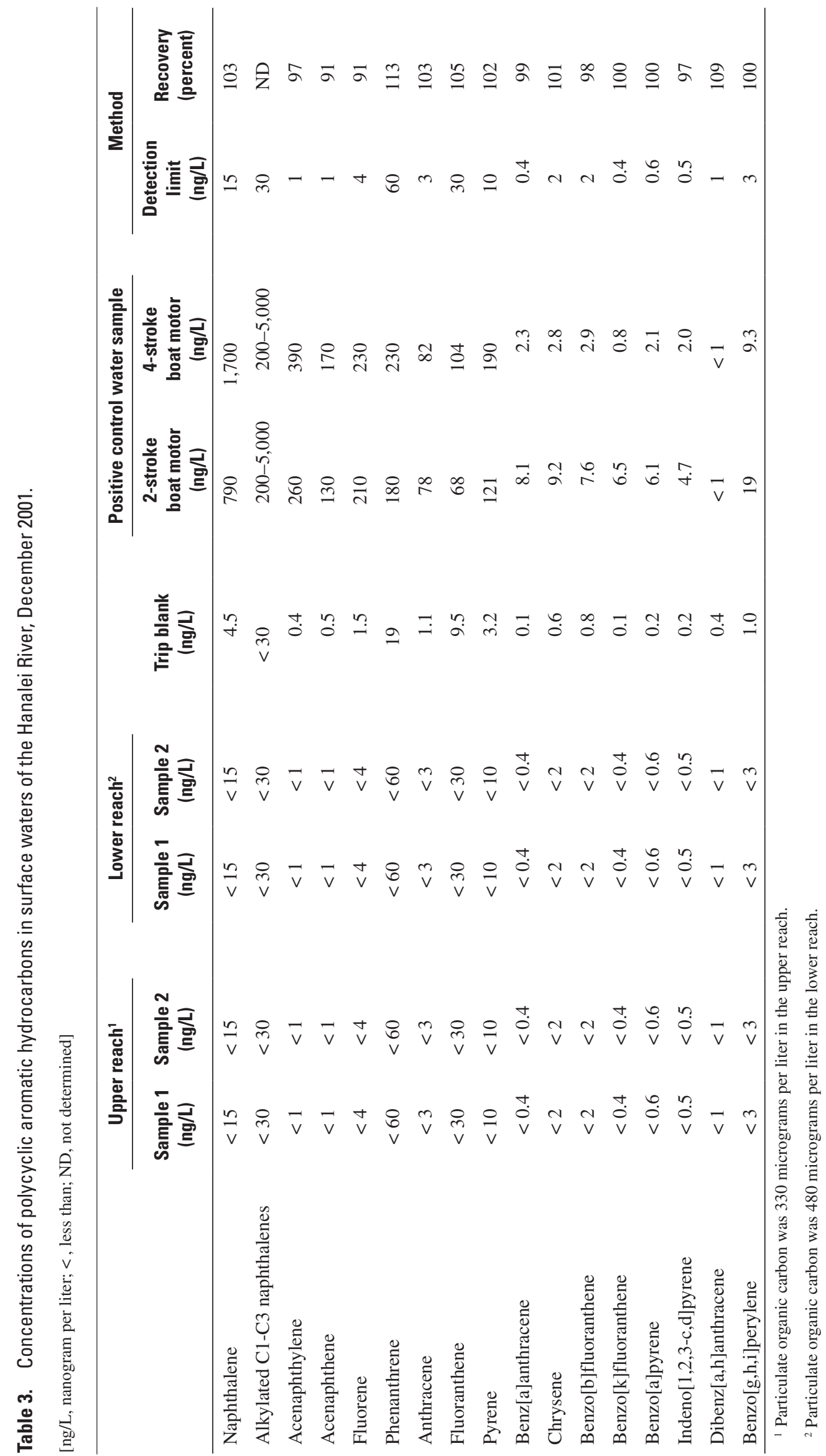



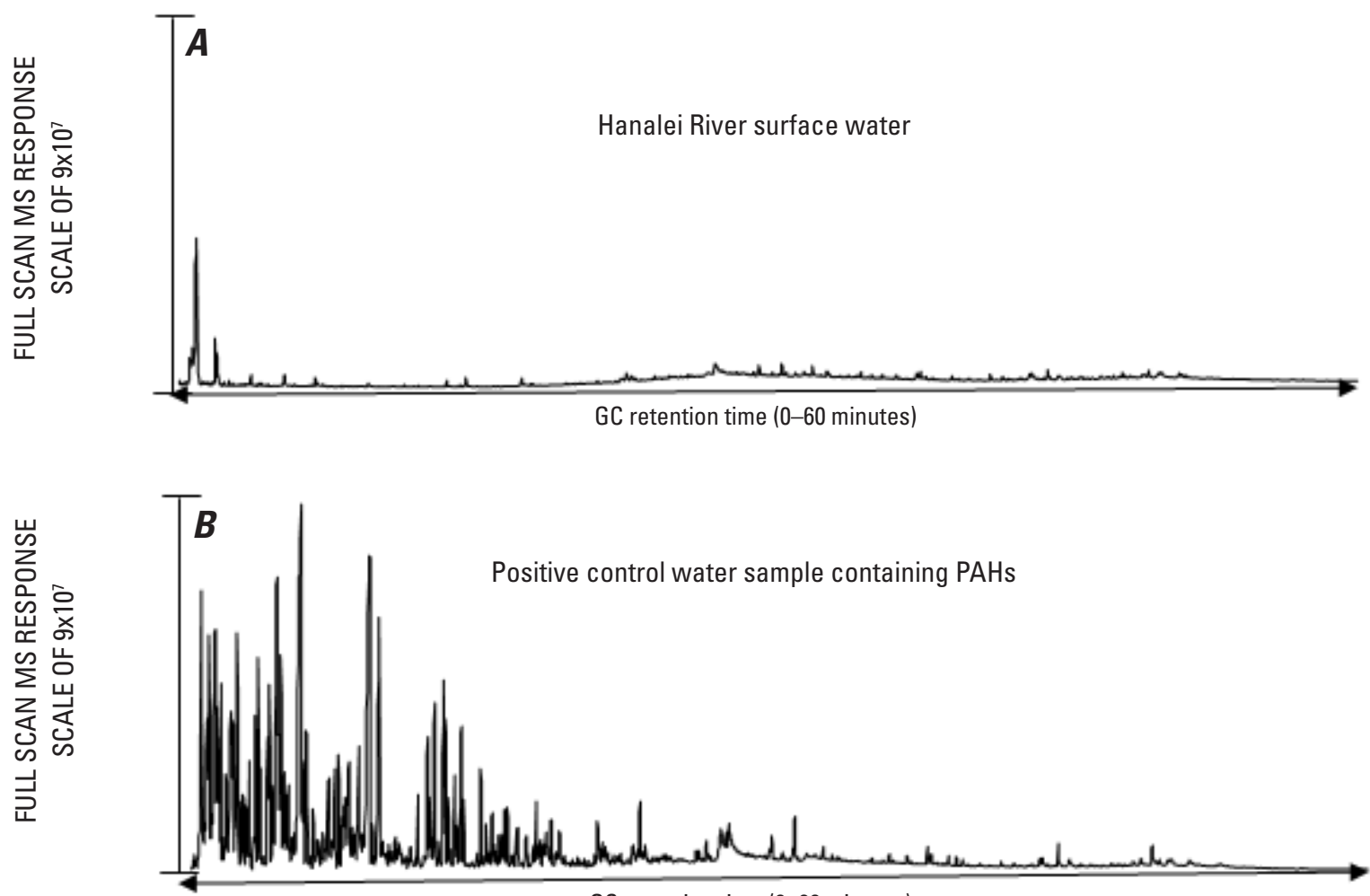

$\mathrm{GC}$ retention time (0-60 minutes)

Figure 3. Comparison of gas chromatography/mass spectrometry (GC/MS) analysis of Hanalei River surface water to that of a positive control water sample containing polycyclic aromatic hydrocarbons (PAH). A, Surface water from the lower reach of Hanalei River shows no PAHs detected. $B$, Positive control water sample containing 4-cycle boat motor exhaust shows PAHs detected.

Sediment Quality Guidelines-Probable Effect Level (CSeQG PEL) and New York State Department of Environmental Conservation (NYSDEC) Wildlife Guidelines (Canadian Council, 1999; Newell and others, 1987). These limits are based on two criteria: (1) At concentrations above the CSeQG PEL, chronic exposure of aquatic biota is expected to result in frequent adverse effects, and (2) the NYSDEC limits are set for protection of fish-eating birds and mammals. The dieldrin, chlordane, and DDE detected in the biota are ubiquitous OC pesticides; they were used in the past to control mosquitoes (DDT) and termites (chlordane and aldrin/dieldrin) (Schmitt and others, 1999). The concentrations of these pesticides in the giant mud crabs and Akupa sleeper fish are below any documented adverse effect levels for fish and wildlife concerns (Peterle, 1997). The relative concentrations of pesticide residues generally followed the relative percent lipids of the Hanalei River Akupa sleeper fish, freshwater Asian clams, and giant mud crabs, at $1.5,0.6$, and 7 percent, respectively.

Generally, differences in element concentrations in Akupa sleeper fish samples from upper and lower reaches were low (table 6). Elemental data for freshwater Asian clams from the upper and lower reaches were similar. Concentrations of mercury, arsenic, selenium, lead, and cadmium were below toxicity levels of concern. Freshwater Asian clams from the upper reach contained about two times higher concentrations of cobalt, vanadium, chromium, nickel, and cadmium. Freshwater Asian clams from the lower reach contained higher arsenic and strontium concentrations indicative of seawater. The giant mud crabs sampled from the lower reach contained elemental concentrations similar to those in the freshwater Asian clams, but with lower concentrations of chromium, cobalt, vanadium, and nickel.

\section{Stream Bed Sediments}

Neither OC pesticides nor PCBs were detected in bed sediments sampled from the upper and lower reaches (table 7). Sediments collected from the lower reach contained PAHs, but samples from the upper reach did not (table 8). PAH patterns were similar in the five sub-samples of the lower reach sediment that were analyzed. One sub-sample had concentrations 15 times higher than the other four, an increase that is likely 
Table 4. Concentrations of elements in surface waters of the Hanalei River, December 2001.

$[\mu \mathrm{g} / \mathrm{L}$, microgram per liter (same as parts per billion); <, less than; ND, not determined; analysis by inductively-coupled plasma-mass spectrometry (ICP/MS) semi-quantitative scan, unless otherwise noted]

\begin{tabular}{|c|c|c|c|c|c|c|}
\hline \multirow[b]{2}{*}{ Element } & \multicolumn{2}{|c|}{ Upper reach } & \multicolumn{2}{|c|}{ Lower reach } & \multicolumn{2}{|c|}{ Quality control } \\
\hline & $\begin{array}{c}\text { Sample } 1 \\
\text { ( } \mu \mathrm{g} / \mathrm{L})\end{array}$ & $\begin{array}{c}\text { Sample } 2 \\
\text { ( } \mu \mathrm{g} / \mathrm{L})\end{array}$ & $\begin{array}{c}\text { Sample } 1 \\
\text { ( } \mu \mathrm{g} / \mathrm{L})\end{array}$ & $\begin{array}{c}\text { Sample } 2 \\
\text { ( } \mu \mathrm{g} / \mathrm{L})\end{array}$ & $\begin{array}{c}\text { Trip blank } 1 \\
\text { ( } \mu \mathrm{g} / \mathrm{L})\end{array}$ & $\begin{array}{c}\text { Trip blank } 2 \\
\text { ( } \mu \mathrm{g} / \mathrm{L})\end{array}$ \\
\hline Alumnium (Al) & 120 & 88 & 280 & 290 & 13 & 9.4 \\
\hline Antimony (Sb) & $<0.1$ & 0.1 & $<0.1$ & 0.3 & $<0.1$ & 0.1 \\
\hline Arsenic $(A s)^{1}$ & $<0.24$ & $<0.24$ & 0.27 & $<0.24$ & $<0.24$ & $<0.24$ \\
\hline Barium (Ba) & 1.4 & 1.4 & 3.6 & 3.6 & $<1$ & $<1$ \\
\hline Cadmium (Cd) & $<0.1$ & 0.2 & $<0.1$ & $<0.1$ & $<0.1$ & $<0.1$ \\
\hline Calcium $(\mathrm{Ca})$ & 4,600 & 4,700 & 38,000 & 37,000 & $<100$ & $<100$ \\
\hline Chromium (Cr) & $<1$ & $<1$ & 1.3 & 1.5 & $<1$ & $<1$ \\
\hline Copper $(\mathrm{Cu})$ & 3.7 & $<1$ & 1.8 & 1.4 & 4.8 & 2.7 \\
\hline Iron $(\mathrm{Fe})$ & 100 & 99 & 530 & 660 & 80 & 54 \\
\hline Lead $(\mathrm{Pb})$ & $<1$ & 17 & $<1$ & $<1$ & $<1$ & $<1$ \\
\hline Lithium (Li) & $<1$ & $<1$ & 13 & 13 & $<1$ & $<1$ \\
\hline Magnesium (Mg) & 4,600 & 4,500 & 110,000 & 100,000 & $<100$ & $<100$ \\
\hline Manganese (Mn) & 4.5 & 4.3 & 40 & 41 & 0.7 & 0.4 \\
\hline Mercury (Hg) & ND & ND & ND & ND & ND & ND \\
\hline Nickel (Ni) & $<1$ & $<1$ & 1.9 & 2.1 & $<1$ & $<1$ \\
\hline Potassium (K) & 440 & 430 & 32,000 & 31,000 & $<100$ & $<100$ \\
\hline Rubidium (Rb) & 0.8 & 0.4 & 13 & 12 & 0.1 & $<0.1$ \\
\hline Selenium $(\mathrm{Se})^{1}$ & $<0.31$ & 0.42 & $<0.31$ & $<0.31$ & $<0.31$ & $<0.31$ \\
\hline Silver (Ag) & 0.1 & $<0.1$ & 0.1 & $<0.1$ & $<0.1$ & $<0.1$ \\
\hline Sodium $(\mathrm{Na})$ & 6,000 & 6,000 & 840,000 & 880,000 & $<100$ & $<100$ \\
\hline Strontium (Sr) & 24 & 24 & 770 & 730 & $<1$ & $<1$ \\
\hline Thallium (Tl) & $<0.1$ & $<0.1$ & $<0.1$ & $<0.1$ & $<0.1$ & $<0.1$ \\
\hline Zinc (Zn) & 2.6 & 17 & 100 & 38 & $<1$ & $<1$ \\
\hline
\end{tabular}

${ }^{1}$ As and Se determined by flow injection hydride generation atomic absorption spectroscopy.

caused by PAH-rich particles. The relative concentrations of the PAHs in the stream bed sediment sample of the lower reach were evaluated to determine likely sources of the PAHs (Laflamme and Hites, 1978). Using the PAH data, several parameters for pattern evaluation pointed to a pyrogenic/combustion sources (among potential sources are campfire and charcoal pit ashes):

(1) ratio of fluoranthene to pyrene ratio was about 1 ,

(2) benzo[a]pyrene was present,

(3) ratio of benzo[e]pyrene to benzo[a]pyrene was about 1 ,

(4) ratio of phenanthrene to anthracene was $>1$.

When comparing concentrations of hydrophobic organic chemicals in samples of the upper and lower reaches, differences in percent organic carbon should be taken into account. The sediments from the upper reach contained very low $(0.8$ percent) organic carbon, while the sediments from the lower reach had 4.1 percent organic carbon and thus a greater capacity to sorb organic chemicals.

Sediments of the lower reach of the river contained noticeably higher concentrations of lithium, sodium, potassium, calcium, arsenic, and strontium (table 9). As was the case with the river water samples under low-flow conditions, seawater influences the stream bed sediment of the lower reach. The source of elevated arsenic is unknown. Stream bed sediments from the upper reach contained barium at levels about five times higher than that of the lower reach. Concentrations of copper, zinc, cadmium, mercury, and lead (197, $315,3.53,0.486$, and $91.3 \mu \mathrm{g} / \mathrm{g}$, respectively) in all Hanalei sediments were less than the PELs ( $\mu \mathrm{g} / \mathrm{g}$ dry weight concentrations) for those elements; whereas, concentrations of chromium and nickel exceeded the PELs of 90 and $36 \mu \mathrm{g} / \mathrm{g}$, respectively (U.S. Environmental Protection Agency, 2000). 


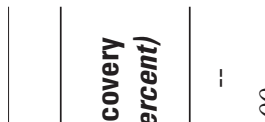
\&

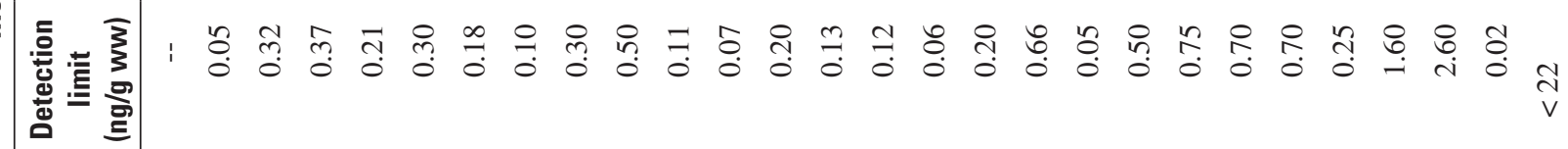





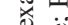

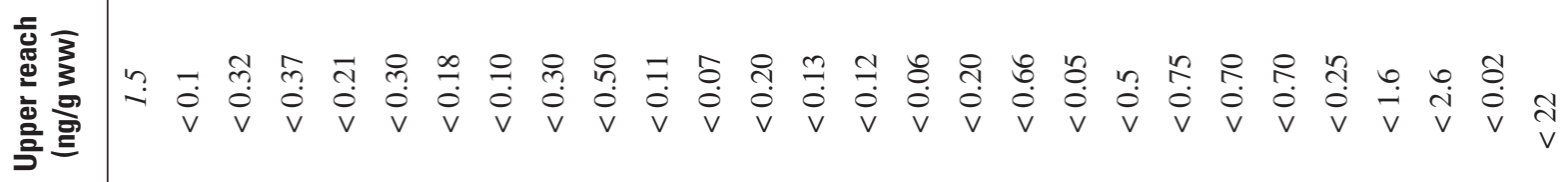


Table 6. Concentrations of elements in Akupa sleeper fish (Eleotris sandwicensis), freshwater Asian clams (Corbicula fluminea), and giant mud crabs (Skylla serrata) of the Hanalei River, December 2001.

$[\mu \mathrm{g} / \mathrm{g}$, micrograms per gram; dw, dry weight; italic type, percent; analysis by inductively coupled plasma with mass spectrometry (ICP/MS) semi-quantitative scan, unless otherwise noted]

\begin{tabular}{|c|c|c|c|c|c|}
\hline \multirow[b]{2}{*}{ Element } & \multicolumn{2}{|c|}{ Akupa sleeper fish } & \multicolumn{2}{|c|}{ Freshwater Asian clams } & \multirow{2}{*}{$\begin{array}{c}\text { Giant mud crabs } \\
\text { Lower reach } \\
(\mu \mathrm{g} / \mathrm{g} \mathrm{dw})\end{array}$} \\
\hline & $\begin{array}{l}\text { Upper reach } \\
(\mu \mathrm{g} / \mathrm{g} d \mathrm{dw})\end{array}$ & $\begin{array}{l}\text { Lower reach } \\
(\mu \mathrm{g} / \mathrm{g} \mathrm{dw})\end{array}$ & $\begin{array}{c}\text { Upper reach } \\
(\mu \mathrm{g} / \mathrm{g} d w)\end{array}$ & $\begin{array}{l}\text { Lower reach } \\
(\mu \mathrm{g} / \mathrm{g} \mathrm{dw})\end{array}$ & \\
\hline Moisture (percent) & 75 & 74 & 92 & 91 & 67 \\
\hline Antimony (Sb) & $<0.1$ & $<0.1$ & $<0.1$ & $<0.1$ & $<0.1$ \\
\hline $\operatorname{Arsenic}(\mathrm{As})^{1}$ & 0.09 & 0.41 & 1.25 & 6.65 & 3.49 \\
\hline Cadmium (Cd) & $<0.1$ & 0.17 & 2.2 & 0.53 & 1.1 \\
\hline Chromium (Cr) & 4.7 & 3.8 & 84 & 31 & 1.8 \\
\hline Cobalt (Co) & 1 & 1.2 & 16 & 7.2 & 2.9 \\
\hline Copper $(\mathrm{Cu})$ & 4.7 & 3.1 & 110 & 110 & 120 \\
\hline Gallium (Ga) & 0.45 & 0.35 & 2.9 & 1.2 & 0.12 \\
\hline Lead $(\mathrm{Pb})$ & $<1$ & $<1$ & 1.2 & $<1$ & $<1$ \\
\hline Mercury $(\mathrm{Hg})^{2}$ & 0.18 & 0.30 & 0.49 & 0.64 & 0.26 \\
\hline Nickel (Ni) & 4.9 & 2.1 & 52 & 26 & 1.3 \\
\hline Selenium $(\mathrm{Se})^{1}$ & 1.39 & 1.86 & 3.94 & 3.26 & 2.98 \\
\hline Silver (Ag) & $<0.1$ & $<0.1$ & 0.15 & 0.36 & 0.16 \\
\hline Strontium $(\mathrm{Sr})$ & 66 & 180 & 24 & 160 & 140 \\
\hline Thallium (Tl) & $<0.1$ & $<0.1$ & $<0.1$ & $<0.1$ & $<0.1$ \\
\hline $\operatorname{Tin}(\mathrm{Sn})$ & 5.8 & 2.4 & $<0.1$ & 0.65 & 0.18 \\
\hline Vanadium (V) & 3.1 & 3.3 & 19 & 7.7 & 0.69 \\
\hline Zinc (Zn) & 79 & 65 & 240 & 240 & 170 \\
\hline
\end{tabular}

${ }^{1}$ As and Se determined by flow injection hydride generation atomic absorption spectroscopy.

${ }^{2} \mathrm{Hg}$ determined by flow injection cold vapor atomic absorption spectroscopy.

The PELs indicate concentrations above which harmful effects are likely to be observed for benthic invertebrates (Hyallela azteca and Chironomus tentans or riparius). However, the bioavailability of metals in sediments depends on several factors (Hansen and others, 2005), so harmful effects cannot be assumed from these data.

\section{Comparison of Contaminant Concentrations in the Hanalei River to Rivers on Oahu}

In 1998, the USGS National Water Quality Assessment Program (NAWQA) sampled selected streams on the Hawaiian Island of Oahu and found concentrations of chlordane and dieldrin in stream bed sediment and fish tissue to exceed guidelines for the protection of birds that eat fish and sediment-dwelling biota (Brasher and others, 1998). Concentra- tions in the streams studied in the Oahu sediments and fish were 100-1,000 times higher than those found in the Hanalei River. Concentrations of dieldrin from urban sites on Oahu at Manoa, Nuuanu, and Kaneohe were 50-300 ng/g (dry weight basis) [reported as micrograms per kilogram $(\mu \mathrm{g} / \mathrm{kg})$ in Brasher and others, 1998], well above the $6.7 \mathrm{ng} / \mathrm{g} \mathrm{CSeQG}$ PEL. Fish-tissue residues of dieldrin from these same sites on Oahu ranged as high as 1,200 ng/g (wet weight basis), exceeding the NYSDEC wildlife guideline of $120 \mathrm{ng} / \mathrm{g}$ for fish. Waikele Stream, an agricultural-area stream on Oahu, and a conservation stream (Waihee), had no dieldrin detected in the fish or stream bed sediment. Chlordane concentrations in the urban sediments of Oahu were 10-40 times the CSeQG PEL. In fish collected from urban sites on Oahu, chlordane concentrations ranged 300-1,900 ng/g, thus ranging to levels much higher that the NYSDEC PEL of $500 \mathrm{ng} / \mathrm{g}$. Concentrations of chlordane in stream sediments and fish from agricultural and conservation areas on Oahu were below $5 \mathrm{ng} / \mathrm{g}$. Total DDTrelated contaminants were highest in streams near agricultural 


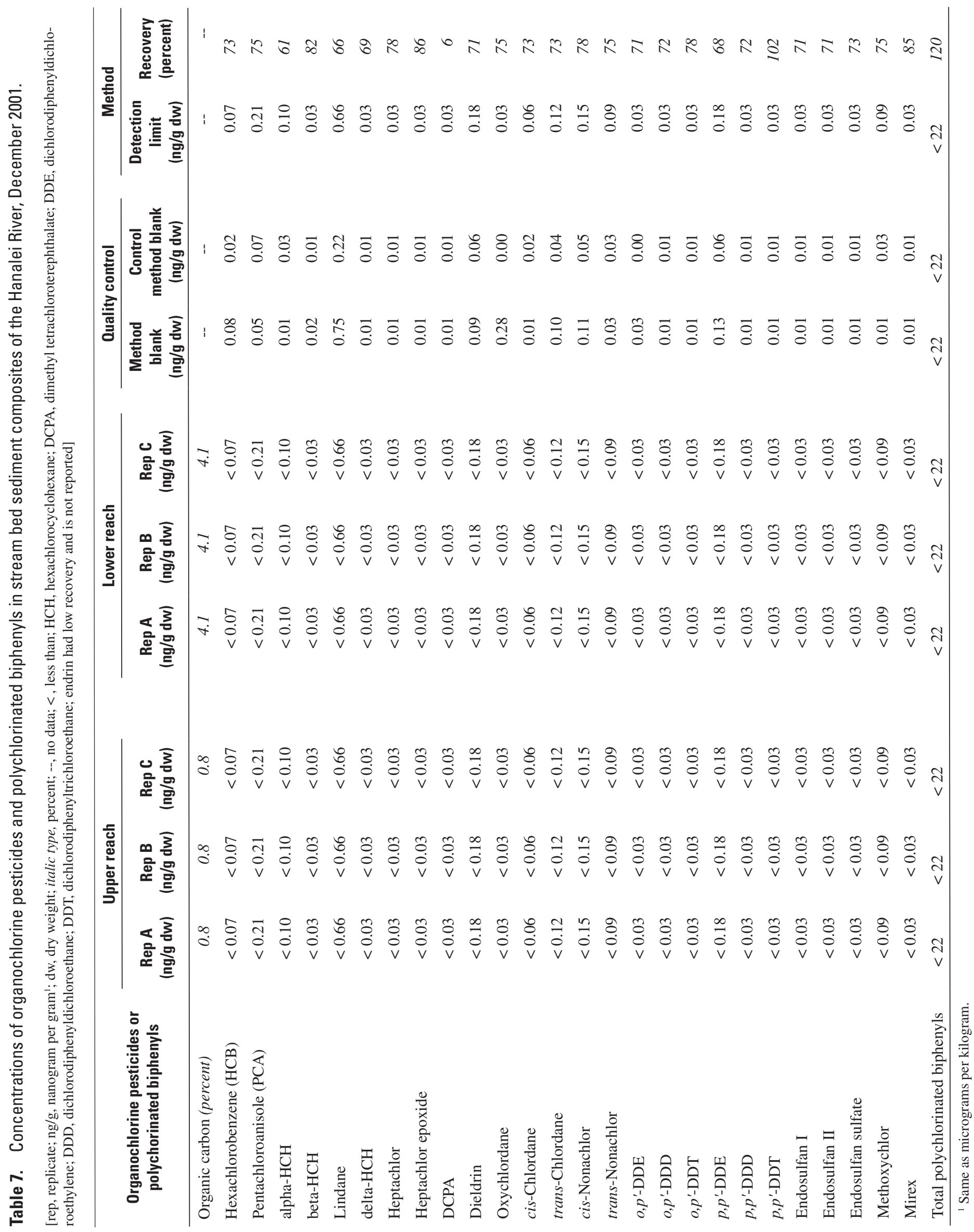




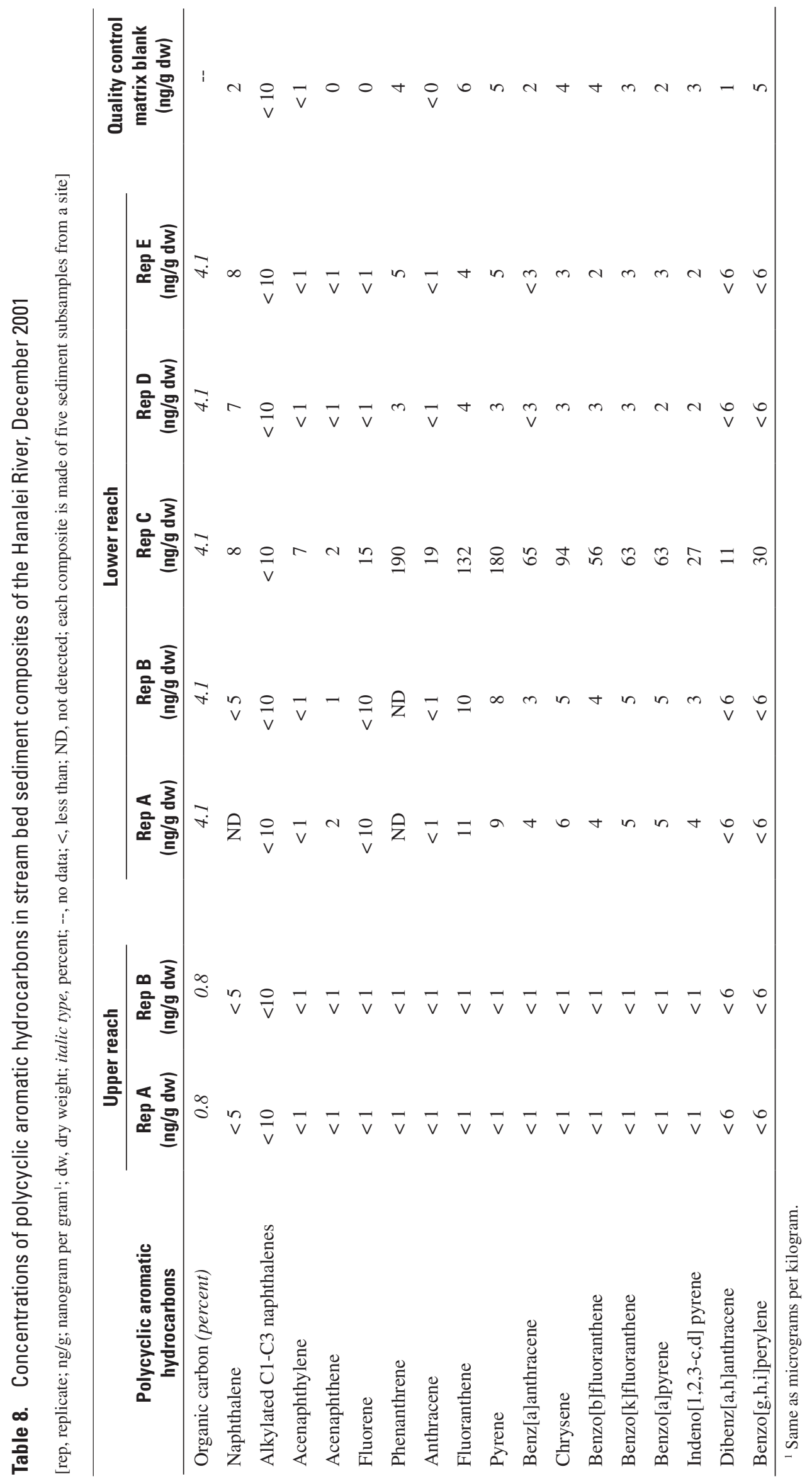


Table 9. Concentrations of elements in stream bed sediment composites of the Hanalei River, December 2001.

$[\mathrm{N}$, number of samples; Std dev, standard deviation; $\mu \mathrm{g} / \mathrm{g}$, micrograms per gram; dw, dry weight, <, less than; --, no data; analyses conducted by inductively-coupled plasma-mass spectrometry in semi quantitative mode, unless indicated otherwise]]

\begin{tabular}{|c|c|c|c|c|}
\hline \multirow[b]{2}{*}{ Element } & \multicolumn{2}{|c|}{ Upper reach } & \multicolumn{2}{|c|}{ Lower reach } \\
\hline & $\begin{array}{c}\text { Mean }(\mathrm{N}=5) \\
(\mu \mathrm{g} / \mathrm{g} \mathrm{dw})\end{array}$ & $\begin{array}{c}\text { Std dev } \\
(\mu \mathrm{g} / \mathrm{g} \mathrm{dw})\end{array}$ & $\begin{array}{c}\text { Mean }(\mathrm{N}=5) \\
(\mu \mathrm{g} / \mathrm{g} \mathrm{dw})\end{array}$ & $\begin{array}{c}\text { Std dev } \\
(\mu \mathrm{g} / \mathrm{g} d w)\end{array}$ \\
\hline Antimony (Sb) & $<0.1$ & -- & $<0.1$ & -- \\
\hline Arsenic $(A s)^{1}$ & 1.2 & 0.60 & 12 & 3 \\
\hline Barium (Ba) & 136 & 11 & 31 & 10 \\
\hline Cadmium (Cd) & 0.16 & 0.08 & 0.15 & 0.01 \\
\hline Calcium (Ca) & 2,440 & 1,110 & 65,200 & 33,200 \\
\hline Chromium (Cr) & 364 & 32 & 274 & 18 \\
\hline Cobalt (Co) & 54 & 3 & 34 & 2 \\
\hline Copper $(\mathrm{Cu})$ & 81 & 9 & 59 & 9 \\
\hline Iron $(\mathrm{Fe})$ & 50,800 & 5,070 & 43,000 & 3,800 \\
\hline Lead $(\mathrm{Pb})$ & 7.7 & 4.3 & 5.2 & 1.2 \\
\hline Magnesium (Mg) & 17,800 & 17,900 & 17,200 & 4,300 \\
\hline Manganese (Mn) & 532 & 336 & 410 & 130 \\
\hline Mercury $(\mathrm{Hg})^{2}$ & 0.04 & 0.01 & 0.06 & 0.02 \\
\hline Nickel (Ni) & 458 & 164 & 290 & 25 \\
\hline Potassium $(\mathrm{K})$ & 138 & 52 & 926 & 307 \\
\hline Selenium $(\mathrm{Se})^{1}$ & 0.38 & 0.16 & 0.62 & 0.22 \\
\hline Silver (Ag) & $<0.1$ & -- & $<0.1$ & -- \\
\hline Sodium (Na) & 318 & 203 & 5,980 & 2,930 \\
\hline Strontium (Sr) & 74 & 13 & 1,210 & 555 \\
\hline Thallium (Tl) & $<0.1$ & -- & $<0.1$ & -- \\
\hline $\operatorname{Tin}(\mathrm{Sn})$ & 0.6 & 0.4 & 0.32 & 0.14 \\
\hline Vanadium (V) & 91 & 3 & 86 & 8 \\
\hline Zinc $(\mathrm{Zn})$ & 124 & 17 & 85 & 9 \\
\hline
\end{tabular}

${ }^{1}$ As and Se determined by flow injection hydride generation atomic absorption spectrophotometry.

${ }^{2} \mathrm{Hg}$ determined by flow injection cold vapor atomic absorption spectrophotometry.

areas, in some cases exceeding the $200 \mathrm{ng} / \mathrm{g}$ NYSDEC PEL. Residues of chlordanes and dieldrin (aldrin degradant) are likely the result of past use for termite and ant control (prior to the 1988 ban of chlordane use in the United States). Chlordane is quite stable in soil environments and so continues to be transported from treated soils near buildings into the watershed (Orazio and others, 1990; Puri and others, 1991). The National Contaminants Biomonitoring Program of the USGS reported that Chinese catfish sampled from the Waikele Stream in 1986 had 140 ng/g dieldrin, and Manoa Stream fish sampled in 1984 contained $1390 \mathrm{ng} / \mathrm{g}$ dieldrin (Schmitt and others, 1999).
Concentrations of PAHs in the 2001 Hanalei River stream bed sediments (from $<1$ to $190 \mathrm{ng} / \mathrm{g}$ ) were less than the concentrations found in urban areas of Oahu (U.S. Geological Survey, 2006). Phenanthrene, fluoranthene, chrysene, pyrene, benzo[a]anthracene and benzo[a]pyrene concentrations of $1,400,1,800,1,000,1,600,770$, and $780 \mathrm{ng} / \mathrm{g}$, respectively, were reported in sediments of Kalauao Stream at Moanalua Road. Other streams on Oahu had PAH concentrations ranging from $<50 \mathrm{ng} / \mathrm{g}$ to several hundred $\mathrm{ng} / \mathrm{g}$. The PAH patterns in Oahu stream bed sediments on Oahu, and the presence of benzo[a]pyrene are indicative of pyrogenic/combustion sources. 
Concentrations of arsenic, selenium, mercury and other toxic metals in the Hanalei River stream bed sediments (table 9) were indicative of natural concentrations in fresh and estuarine waters of Hawai'i. Trace element concentrations in Hanalei River stream bed sediments were similar to or less than stream bed sediments from selected streams on the Island of Oahu (from 1998 to 2000) (Brasher and others, 2000). Reported mercury concentrations on Oahu ranged 0.06-0.2 $\mu \mathrm{g} / \mathrm{g}$ (dry weight), and were indistinguishable from the Hanalei River stream bed sediments at the upper and lower reaches, which ranged $0.025-0.09 \mu \mathrm{g} / \mathrm{g}$ (dry weight). Concentrations of arsenic and selenium in the Hanalei River were also similar to concentrations in stream bed sediments on Oahu.

\section{Summary}

This study measured certain persistent organic chemicals and elements in samples collected from the Hanalei River during a relatively low-flow period in December of 2001. Akupa sleeper fish, freshwater Asian clams, giant mud crabs, surface waters, and stream bed sediments were collected from a lower, estuarine reach near Hanalei Bay and from a freshwater reach at the HNWR. Very low or non-detectable concentrations of OC pesticides, PCBs, PAHs, alkylated PAHs, aliphatic hydrocarbons, mercury, arsenic, selenium, cadmium, and lead were found. Concentrations of these organic compounds and elements were below probable adverse effects screening levels set by USEPA for aquatic organisms. The chemicals targeted by this study are a subset of the myriad of potential contaminants associated with urban and agricultural activities. Inclusion of additional chemicals such as those associated with wastewater treatment effluents, right-of-way and golf course maintenance, and chemicals of emerging concern would provide a more complete description of the occurrence of pollutant chemicals. Periodic monitoring of the Hanalei River for chemical contaminants would provide valuable information for managing this American Heritage River.

\section{Acknowledgments}

We thank the staff of the Kilauea Point Natural History Association and the Hanalei Watershed Hui for their support of USGS biological resources research. Mahalo (thank you) to Hui Executive Director Makaala Kaaumoana. Thanks also to State Fisheries Biologist, Don Heacock, and his team for their time and effort in the collection of samples. We appreciate the contributions from the team of environmental chemists at USGS: Ray Wiedmeyer and Michael Walther for trace elements analysis and Kevin Feltz, George Tegerdine, and Paul Peterman for the organic chemical contaminant analyses.

\section{References Cited}

Brasher, A.M., and Anthony, S.S., 2000, Occurrence of organochlorine pesticides in stream bed sediment and fish from selected streams on the Island of Oahu, Hawai' i, 1998: U.S. Geological Survey Fact Sheet 140-00.

Canadian Council of Ministers of the Environment, 1999, Canadian sediment quality guidelines for the protection of aquatic life, summary tables, 1999: Winnipeg, Can., Canadian Council of Ministers of the Environment, accessed August 2002 at URL http://www.ec.gc.ca/ceqg-rcqe.

Calhoun, R.S., Fletcher, C.H., and Harney, J.N., 2002, A budget of marine and terrigenous sediments, Hanalei Bay, Kaua'i, Hawaiian Islands: Sedimentary Geology, v. 150, n. 1 , p. 61-87.

Hansen, D., Ditoro, D.M., Berry, W.J., Boothman, W.S., Burgess, R.M., Ankley, G.T., Mount, D.R., Mcgrath, J.A., Derosa, L.D., Bell, H.E., Reiley, M.C., and Zarba, C.S., 2005, Procedures for deriving equilibrium partitioning sediment benchmarks (ESBs) for the protection of benthic organisms - metals mixtures (cadmium, copper, lead, nickel, silver, and zinc): Washington, D.C., U.S. Environmental Protection Agency, EPA/600/R-02/011 (NTIS PB2006-102425).

Keith, L.H., 1991, Environmental sampling and analysisa practical guide: Boca Raton, Fla., Lewis Publishers, p. 93-119.

LaFlamme, R.E., and Hites, R.A.,1978, The global distribution of PAH in recent sediments: Geochimica et Cosmochimica Acta, v. 42, p. 289-303.

Lebo, J.A., Zajicek, J.A., Orazio, C.E., Petty, J.D., and Huckins, J.N., 1996, Use of semipermeable membrane devices (SPMDs) to sample polycyclic aromatic hydrocarbon pollution in a lotic system: Polycyclic Aromatic Compounds, v. 8, p. 53-65.

Lyman, W.J., Reehl, W.F., and Rosenblatt, D.H., 1990, Handbook of chemical property estimation methods: Washington, D.C., American Chemical Society, Chapter 4, 5, p. 1-30.

Neff, J.M., 1979, Polycyclic aromatic hydrocarbons in the aquatic environment-sources, fate, and biological effects: London, Applied Science Publishers Ltd, p. 7-33.

Newell, A.J., Johnson, D.W., and Allen, L.K., 1987, Niagra River biota contamination project-fish flesh criteria for piscivorous wildlife, in Bureau of Environmental Protection Technical Report \#87-3: New York State Department of Environmental Conservation, Division of Fish and Wildlife, p. 182. 
Orazio, C., Kapila, S., Meadows, J., Puri, R., and Yanders, A., 1990, Field and laboratory studies on sources and persistence of chlordane contamination in the Missouri aquatic environment: Chemosphere, v. 20, no. 11, p. 1581-1588.

Peterle, T.J., 1997, Wildlife toxicology: New York, Van Norstrand Reinhold, p. 133-187.

Petty, J.D., Orazio, C.E., Huckins, J.N., Gale, R.W., Lebo, J.A., Meadows, J.C., Echols, K.R., and Cranor, W.L., 2000, Considerations involved with the use of semipermeable membrane devices for monitoring environmental contaminants: Journal of Chromatography, v. 879, p. 83-95.

Puri, R., Orazio, C., Kapila, C., Clevenger, T., Yanders, A., McGrath, K., Buchanan, A., Czarnezki, J., and Bush, J., 1990, Studies on the transport and fate of chlordane in the environment-long range transport of pesticides: Boca Raton, Fla., CRC Press, Inc., p. 271-289.

Schmitt, C.J., Ludke, J.L., and Walsh, D.F., 1981, Organochlorine residues in fish-national pesticide monitoring program, 1970-1974: Journal of Pesticide Monitoring, no. 4, p. 136-206.

Schmitt, C.J., Zajicek, J.L., and Peterman, P.H., 1990, National contaminant biomonitoring program-residues of organochlorine chemicals in freshwater fish, 1976-1984: Archives of Environmental Contamination and Toxicology, v. 19 , no. 5 , p. $748-781$.

Schmitt, C.J., Zajicek, J.L., May, T.W., and Cowman, D.F. 1999, Organochlorine residues and elemental contaminants in U.S. freshwater fish, 1976-1986, National Contaminant Biomonitoring Program: Reviews of Environmental Contamination and Toxicology, v. 162, p. 43-104.

U.S. Department of Agriculture/Syracuse Environmental Research Associates, Inc., 1999, Selected commercial formulations of glyphosate-Accord, Rodeo, Roundup and Roundup Pro-risk assessment final report prepared for the USDA, Forest Service; SERA TR 96-22-02-01C: Syracuse, N.Y., Syracuse Research Corporation, accessed January 2003 at URL http://www.fs.fed.us/foresthealth/pesticide.

U.S. Environmental Protection Agency, 1999, National recommended water quality criteria-correction: Washington, D.C., U.S. Environmental Protection Agency, Office of Water, EPA 822-Z-99-001, p. 60664-60665.

U.S. Environmental Protection Agency, 2000, Prediction of sediment toxicity using consensus-based freshwater sediment quality guidelines: Chicago, Ill., U.S. Environmental Protection Agency, GLNPO, EPA 905/R-00/007.

U.S. Geological Survey, 2006, National Assessment of Water Quality (NAWQA): U.S. Geological Survey, accessed December 2006 at URL http://water.usgs.gov/nawqa/constituents.
U.S. Geological Survey, 2007, USGS surface-water daily statistics for Hawai'i: U.S. Geological Survey, accessed April 2007 at URL http://waterdata.usgs.gov/hi/nwis.

U.S. Fish and Wildlife Service, 2000, A study on the effects of golf course organophosphates and carbamate pesticides on endangered cave-dwelling arthropods, Kaua'i, Hawai'i: U.S. Fish and Wildlife Service, accessed December 2006 at URL http://www.fws.gov/pacific/ecoservices/enicon/pim/ reports/Hawaii/Golfcaves.html.

U.S. Fish and Wildlife Service, 2006, Pacific Islands-Hanalei National Wildlife Refuge: Kilauea, Hawai'i, U.S. Fish and Wildlife Service, accessed December 2006 at URL http:// www.fws.gov/pacificislands/wnwr/khanaleinwr.html.

Wang, N., Besser, J.M., Buckler, D.R., Honegger, J.L., Ingersoll, C.G., Johnson, B.T., Kurtzweil, M.L., MacGregor, J., and McKee, M.J., 2005, Influence of sediment on the fate and toxicity of a polyethoxylated tallowamine surfactant system in aquatic microcosms: Chemosphere, v. 59, no. 4, p. 545-551. 


\section{Appendices}

Appendix 1. Persistent organic chemicals.

\section{Organic chemical class}

Chemical name(s)
Principal uses and sources to aquatic ecosystems

\author{
Aldrin \\ cis-Chlordane \\ trans-Chlordane \\ $o, p$-Dichlorodiphenyldichloroethane \\ (DDD) \\ $o, p^{\prime}$-Dichlorodiphenyldichloroethylene \\ (DDE) \\ $o, p^{\prime}$-Dichlorodiphenyltrichloroethane \\ (DDT) \\ $p, p^{\prime}-\mathrm{DDD}$ \\ $p, p^{\prime}-\mathrm{DDE}$ \\ $p, p^{\prime}$-DDT
}

Dieldrin

Dimethyl tetrachloroterephthalate (DCPA)

\section{Endrin}

Endosulfan I (a-Endosulfan)

Endosulfan II (b-Endosulfan)

Endosulfan sulfate

Heptachlor

Heptachlor epoxide

Hexachlorobenzene (HCB)

alpha-Hexachlorocyclohexane ( $\mathrm{HCH})$ 1,2,3,4,10,10-hexachloro-1,4,4a,5,8,8a-hexahydro-1,4:5,8-dimethanonaphthalene

1,2,4,5,6,7,8,8-octachloro-2,3,3a,4,7,7a-hexahydro-4,7-methano-1H-indene (1- $\alpha, 2-\alpha, 3 \mathrm{a}-\alpha, 4-$ $\beta, 7-\beta, 7 \mathrm{a}-\alpha)$

1,2,3,4,5,6,7,8,8-nonachloro-2,3,3a,4,7,7a- hexahydro-4,7-methano-1H-indene (1- $\alpha, 2-\beta, 3-\alpha$, $3 a-\alpha, 4-\beta, 7-\beta, 7 a-\alpha)$

2-(o-chlorophenyl)-2-( $p$-chlorophenyl)-1,1-dichloroethane

2-(o-chlorophenyl)-2-( $p$-chlorophenyl)-1,1-dichloroethylene

2-(o-chlorophenyl)-2-(p-chlorophenyl)-1,1,1-trichloroethane

2,2-bis ( $p$-chlorophenyl)-1,1-dichloroethane

2,2-bis (p-chlorophenyl)-1,1-dichloroethylene

2,2-bis ( $p$-chlorophenyl)-1,1,1-trichloroethane

1,2,3,4,10,10-hexachloro-6,7-epoxy-1,4,4a,5,8,8ahexahydro-1,4-endnnno-exo-5,8-dimethanonaphthalene

dimethyl-2,3,5,6-tetrachlorobenzene-1,4-dicarboxylic acid

1,2,3,4,10,10-hexachloro-6,7-epoxy1,4,4a,5,6,7,8,8a-octahdyro-1,4- endo-endo5,8-dimethanonaphthalene

6,9-methano-2,4,3-benzodioxathiepin, 6,7,8,9,10,10-hexachloro-1,5,5a,6,9,9a

6,7,9,10,10-hexachloro-1,5,5a,6,9,9a-hexahydro6,9-methano-2,4,3-benzodiozathiepin-3-oxide, (3a, 5aa, 6b, 9b, 9aa)

6,7,8,9,10,10-hexachloro-1,5,5a,6,9,9a-hexahydro-6,9-methano,2,4,3-benodiatiepin 3,3-dioxide

1H-1,4,5,6,7,8-8-heptachloro-3a,4,7,7a-tetrahydro-4,7-methanoindene

1,4,5,6,7,8,8-heptachloro-2,3-epoxy-3a,4,7,7a-tetrahydro-4,7-methano-1H-indene

Perchlorobenzene

1,2,3,4,5,6-hexachlorocyclohexane
Insecticide

Insecticide; technical chlordane constituent

Technical chlordane constituent

$o, p^{\prime}$-DDT metabolite

$o, p^{\prime}$-DDT metabolite

$p, p^{\prime}$-DDT impurity

Insecticide; DDT-metabolite

DDT-metabolite

Insecticide

Insecticide; aldrin metabolite

Herbicide; may contain dioxin $(2,3,7,8$-TCDD) and HCB as impurities

Insecticide; isodrin metabolite

Pesticide

Pesticide

Endosulfan byproduct

Insecticide

Heptachlor metabolite; technical chlordane constituent/metabolite

Fungicide; industrial intermediate

Constituent of insecticide mixture containing various $\mathrm{HCH}$ isomers; also known as a-benzene hexachloride $(\mathrm{BHC})$ 
Appendix 1. Persistent organic chemicals. - Continued

\begin{tabular}{|c|c|c|}
\hline Organic chemical class & Chemical name(s) & $\begin{array}{l}\text { Principal uses and sources to } \\
\text { aquatic ecosystems }\end{array}$ \\
\hline beta-Hexachlorocyclohexane (HCH) & 1,2,3,4,5,6-hexachlorocyclohexane & Technical HCH (BHC) constituent \\
\hline delta-Hexachlorocyclohexane $(\mathrm{HCH})$ & 1,2,3,4,5,6-hexachlorocyclohexane & Technical HCH (BHC) constituent \\
\hline $\begin{array}{l}\text { gamma-Hexachlorocyclohexane }(\mathrm{HCH}) \\
\text { (Lindane) }\end{array}$ & 1,2,3,4,5,6-hexachlorocyclohexane & $\begin{array}{l}\text { Insecticide; technical } \mathrm{HCH}(\mathrm{BHC}) \\
\text { constituent }\end{array}$ \\
\hline Methoxychlor & $\begin{array}{l}\text { 1,1'-(2,2,2-trichloroethylidene)-bis[4-methoxy- } \\
\text { benzene] }\end{array}$ & Insecticide \\
\hline Mirex & $\begin{array}{l}\text { 1,1a,2,2,3,3a,4,5,5,5a,5b,6-dodecachloro- octahy- } \\
\text { dro-1,3,4-metheno-1H-cyclobuta(cd)pentalene }\end{array}$ & Insecticide; fire retardant \\
\hline cis-Nonachlor & $\begin{array}{l}\text { 1,2,3,4,5,6,7,8,8-nonachloro- } 2,3,3 \mathrm{a}, 4,7,7 \mathrm{a}-\text { hexa- } \\
\text { hydro-4,7-methano-1H-indene }(1-\alpha, 2-\alpha, 3-\alpha, \\
\text { 3a- } \alpha, 4-\beta, 7-\beta, 7 \mathrm{a}-\alpha)\end{array}$ & Technical chlordane constituent \\
\hline trans-Nonachlor & $\begin{array}{l}\text { 1,2,3,4,5,6,7,8,8-nonachloro- } 2,3,3 \mathrm{a}, 4,7,7 \mathrm{a}-\mathrm{hexa}- \\
\text { hydro-4,7-methano-1H-indene( } 1-\alpha, 2-\beta, 3-\alpha \\
\text { 3a- } \alpha, 4-\beta, 7-\beta, 7 \mathrm{a}-\alpha)\end{array}$ & Technical chlordane constituent \\
\hline Oxychlordane & $\begin{array}{l}\text { 2,3,4,5,6,6a,7,7-octachloro-1a, } 1 \mathrm{~b}, 5,5 \mathrm{a}, 6,6 \mathrm{a} \text {-hexa- } \\
\text { hydro- } 2,5 \text {-methano- } 2 \mathrm{H} \text {-indeno(1,2-b)oxirene } \\
(1 \mathrm{a}-\alpha, 1 \mathrm{~b}-\beta, 2-\alpha, 5-\alpha, 5 \mathrm{a}-\beta, 6-\beta, 6 \mathrm{a}-\alpha)\end{array}$ & cis-Chlordane metabolite \\
\hline Pentachloroanisole & Chlorinated benzene & Metabolite of pentachlorophenol \\
\hline Pentachlorobenzene & Chlorinated benzene & Fungicide; fire retardant \\
\hline Polychlorinated biphenyls (PCBs) & $\begin{array}{l}\text { Mixture containing as many as } 209 \text { mono- } \\
\text { through nona-chloro-substituted biphenyl } \\
\text { congeners. }\end{array}$ & $\begin{array}{l}\text { Dielectric, hydraulic, and transformer } \\
\text { fluids; lubricants; extenders; de- } \\
\text { dusting agents; carbonless copy } \\
\text { paper }\end{array}$ \\
\hline Toxaphene & $\begin{array}{l}\text { Chlorinated camphene mixture averaging } 62 \% \\
\text { chlorine by weight }\end{array}$ & Insecticide; herbicide \\
\hline
\end{tabular}

Appendix 2. Elements.

\begin{tabular}{|c|c|c|}
\hline Analyte & $\begin{array}{l}\text { Atomic } \\
\text { symbol }\end{array}$ & $\begin{array}{l}\text { Principal uses and sources to } \\
\text { aquatic ecosystems }\end{array}$ \\
\hline Cadmium & $\mathrm{Cd}$ & Mining, smelting and other industrial sources; urban runoff; sewage discharges \\
\hline Chromium & $\mathrm{Cr}$ & Mining, tanning, and other refractory and chemical industrial sources \\
\hline Lead & $\mathrm{Pb}$ & $\begin{array}{l}\text { Mining, smelting and other industrial sources; urban runoff; atmospheric pollution; fishing } \\
\text { sinkers; lead shot }\end{array}$ \\
\hline Mercury & $\mathrm{Hg}$ & $\begin{array}{l}\text { Herbicides; fungicides; pulp, paper, and textile effluents; open-cycle chloralkali cells; land- } \\
\text { fills; mining; atmospheric pollution }\end{array}$ \\
\hline Zinc & $\mathrm{Zn}$ & Mining, smelting and other industrial sources; urban runoff \\
\hline
\end{tabular}


For more information concerning the research described in this report, contact:

U.S. Geological Survey Columbia Environmental Research Center 4200 New Haven Road Columbia, Mo 65201

(573) 875-5399

http://www.cerc.usgs.gov 

